\title{
Anthropogenic extinction of Pacific land snails: A case study of Rurutu, French Polynesia, with description of eight new species of endodontids (Pulmonata)
}

ANDRÉ F. SARTORI ${ }^{1}$, OLIVIER GARGOMINY² \& BENOÎT FONTAINE ${ }^{3}$

Muséum National d'Histoire Naturelle, 55 rue Buffon, 75005 Paris, France. Email: ${ }^{1}$ andrefsartori@gatesscholar.org; ${ }^{2}$ gargo@mnhn.fr; ${ }^{3}$ fontaine@mnhn.fr 


\begin{abstract}
Faunistic surveys are fundamental in the conservation of land mollusks, particularly as a means of achieving accurate estimates of species richness and levels of extinction of endangered taxa. The family Endodontidae comprises one of the most diverse groups of indigenous land snails of Pacific Islands. Due to anthropogenic degradation of their habitats, most members of the family are now extinct or severely endangered. In Rurutu, French Polynesia, 11 species of Endodontidae were previously described (10 endemics), but only 1 is known to have been extant during the first half of the 20th Century. Extensive collections made in Rurutu in 2003 recovered only empty shells of these 11 species, as well as of an additional 8 endemic species of endodontids not known to previous investigators: Australdonta oheatora sp. nov., A. anneae sp. nov., A. sibleti sp. nov., A. florencei sp. nov., A. pakalolo sp. nov., A. teaae sp. nov., Minidonta boucheti sp. nov. and M. bieleri sp. nov. The radiation of endodontids in Rurutu was thus much larger than previously envisaged. However, we hypothesize that all species of the family are now extinct in the island.
\end{abstract}

Keywords: Conservation, biodiversity, endangered, islands, systematics, mollusk. 


\section{Introduction}

Mollusks account for more than half of extinctions recorded in the current biodiversity crisis $($ Regnier et al. 2009$)$. Within the phylum, the indigenous land snail fauna of Pacific islands - characterized by high levels of species richness and endemism - comprise the most vulnerable group (Lydeard et al. 2004). Mainly due to habitat loss and introduction of alien species, these unique faunas are rapidly disappearing (Bauman 1996; Cowie 2001; Cowie \& Robinson 2003).

Of the thirteen major families of land snails native to the Pacific islands (Cowie 1996, table 1), Endodontidae Pilsbry, 1895 may have been the most speciose (Solem 1976). Endodontids are essentially ground dwellers characterized by a small, depressed shell, with the aperture typically narrowed by ridge-like barriers. In the Austral Islands, French Polynesia, the family went through a spectacular radiation before being almost completely demised by anthropogenic degradation of its habitats (Solem 1976).

Mostly based on material from the Bishop Museum's Mangarevan Expedition (Gregory 1935, 1936), Solem (1976, 1983) recorded 2 species of Endodontidae inhabiting Rimatara, 7 in Rurutu, 3 in Tubuai, 7 in Raivavae and 24 in Rapa. The malacofauna of most Austral Islands was not surveyed again throughout the 20th Century.

Faunistic surveys and taxonomic studies are paramount in the conservation of land mollusks, particularly as a means of achieving an accurate estimate of the true levels of species richness and extinction (Lydeard et al. 2004). In 2003, extensive collections were made in Rurutu as part of a multi-disciplinary effort to inventory and assess the conservation status of the biodiversity of the island (Gargominy \& Fontaine 2003; Meyer 
\& Claridge in press). Twelve species of Endodontidae not known to previous investigators were present in the recovered material. Four of these were formally described by Zimmermann et al. (2009), and the eight remaining comprise the subject of this paper. All of them, as hypothesized here, went extinct before being known to science.

\section{Material and Methods}

Specimens were collected during a malacological survey of Rurutu, conducted from the 17 th to the 30 th November 2003. Seventy localities were sampled, 44 of which in areas of raised coral-reef (matos) that are particularly rich in mollusks (Table 1, Fig. 1). Two methods of collection were used: (1) specimens were located visually and hand picked; (2) samples of soil and leaf litter were sieved through a 1-cm mesh; the residue was then dried and sieved through meshes of 3,2 and $0.63 \mathrm{~mm}$; material retained by these finer sieves was surveyed for snails, using a stereo-microscope for the fraction between 2 and $0.63 \mathrm{~mm}$. The fraction below $0.63 \mathrm{~mm}$ was discarded. All recovered material, including approximately 17,000 endodontid empty shells, is lodged in the collections of the Muséum national d'Histoire naturelle, Paris (MNHN).

[FIGURE 1 approximately here]

[Table 1 approximately here]

Prior to imaging, selected specimens were immersed in water, cleaned with fine brushes and air-dried. Stacks of photographs were taken using a digital single-lens reflex camera attached to a stereo-microscope. Composite images with extended depth of field were then created by processing these stacks in 
CombineZP (Hadley 2010). Scanning electron microscopy (SEM) was conducted on uncoated material, including holotypes and paratypes.

Measurements of shell diameter (d) and height (h), spire protrusion (sp), umbilicus diameter $(\mathrm{u})$, aperture height (ah) and aperture width (aw) were taken using a stereo-microscope equipped with an ocular micrometer; number of whorls (nw) and number of ribs on body whorl (nr) were counted in photographs taken in apical view (see Fig. 2 for the placement of measurements).

[FIGURE 2 approximately here]

Apertural barriers were numbered according to the system used by Solem (1976) and Zimmermann et al. (2009): those on the parietal wall counted from the apical to the umbilical suture, and those on the palatal wall in the opposite direction (Fig. 2D). Within each wall, apertural traces were counted separately from major barriers.

\section{Systematic descriptions}

Order Pulmonata Cuvier in Blainville, 1814

Suborder Stylommatophora Schmidt, 1855

Superfamily Punctoidea Morse, 1864

Family Endodontidae Pilsbry, 1895

Genus Australdonta Solem, 1976

Australdonta Solem, 1976: 289. Type species (by original designation):

Australdonta raivavaeana Solem, 1976.

Australdonta oheatora sp. nov. 
Figures 3A, 4, 14A, 15A

Examined material (48 specimens). Holotype: MNHN 25193, Rr66. Paratypes: MNHN 25194, 8 shells, Rr66. Additional material: 35 shells, Rr66; 3 shells, Rr38; 1 shell, Rr68.

Diagnosis: Shell small, relatively high, with a shallow supraperipheral groove, without flammulations; palatal wall devoid of barriers; parietal wall with three to five barrier traces.

Description: Shell subdepressed, white to light fawn, without markings. Shell thin, opaque to pellucid; periostracum adherent, shiny. Apex flat to moderately raised, spire elevated; later whorls descending progressively more rapidly. Whorls weakly keeled peripherally; apical suture canaliculate, umbilical suture impressed. Transition between protoconch and teleoconch indistinct. Protoconch and initial teleoconch rounded in cross-section; developing a shallow supraperipheral groove extending approximately from the first quarter of the third whorl onwards. Protoconch sculptured by very fine, widely spaced spiral and axial lirae, forming a reticulated pattern; spiral lirae wobbly in aspect, particularly towards the shell axis, fading on the transitional zone between protoconch and teleoconch. Axial lirae progressively transitioning into more crowded and slightly coarser riblets, with interspaces two to four times their width, overlaying the primary axial sculpture of the teleoconch. Primary axial sculpture formed by broad, low ribs or undulations of the external shell surface, with interspaces approximately three times their width. Umbilicus wide, deep. Peristome ovate, slightly constricted by supraperipheral sulcus. Palatal barriers lacking. Parietal barriers usually represented by three, seldom by four or rarely by five traces, all extending for approximately one quarter of a whorl; first trace 
located very near the suture, slightly taller than the remainder; second trace rarely present, slightly lower than the third and fourth traces; third and fourth traces located in the central sector of the parietal lip, very similar in morphology; fifth trace, when present, just abaxial to the umbilical suture, slightly lower and more slender than the third and fourth traces. Other shell features that can be expressed numerically are shown in Table 2 .

Remarks: The higher shell, fine axial riblets, lack of palatal barriers and narrower umbilicus of $A$. oheatora immediately separate this species from previously described Australdonta with marked supraperipheral grooves, namely A. magnasulcata Solem, 1976, A. magnasulcatissima Zimmermann et al., 2009 and A. sulcata Zimmermann et al., 2009. A much deeper supraperipheral groove distinguishes $A$. anneae sp. nov. from A. oheatora.

Etymology: Oheatora is the ancient Polynesian name of the island of Rurutu. It is treated as a noun in apposition.

[FIGURE 3 approximately here]

[FIGURE 4 approximately here]

\section{Australdonta anneae sp. nov.}

Figures $3 \mathrm{~B}, 5,14 \mathrm{~B}, 15 \mathrm{~B}$

Examined material (3 specimens). Holotype: MNHN 25197, Rr43. Paratypes: MNHN 25198, 2 shells, Rr38.

Diagnosis: Shell with a very deep supraperipheral groove, without flammulations; aperture displaying only a few barrier traces (one palatal and one or two parietal). 
Description: Shell depressed, white to light fawn, without markings. Shell thin, sub-pellucid to pellucid; periostracum adherent, shiny. Spire barely elevated, descending at an irregular rate and ascending slightly for approximately the first half of the second whorl. Whorls keeled peripherally and supraperipherally, imbricated; apical suture canaliculate, umbilical suture impressed. Transition between protoconch and teleoconch indistinct. Protoconch and initial teleoconch rounded in cross-section; developing a deep supraperipheral groove extending approximately from the first quarter of the third whorl onwards, delimiting two rounded keels. Protoconch sculptured by very fine spiral and axial lirae, forming a reticulated pattern; spiral lirae wobbly in aspect, fading on the transitional zone between protoconch and teleoconch. Axial lirae progressively transitioning into more crowded and slightly coarser riblets, with interspaces approximately twice their width, overlaying the primary axial sculpture of the teleoconch. Primary axial sculpture formed by broad, low ribs or undulations of the external shell surface, with interspaces two to three times their width. Straight spiral riblets visible on portions of the teleoconch surface, often in the vicinity of the apical suture. Umbilicus wide, shallow. Peristome subovate, constricted by deep sulcus between peripheral and supraperipheral keels. Apertural barriers represented by one palatal and one or two parietal traces, all extending inwards beyond the line of vision from the peristome. Palatal trace supraperipheral, positioned very near the suture, slightly narrower and less projecting than parietal traces. First parietal trace, when present, located very near the suture; second parietal trace in the middle of the parietal lip. Other shell features that can be expressed numerically are shown in Table 2 ,

Remarks: A deep supraperipheral groove demarcating two prominent 
keels is a unique feature of this species, which easily distinguishes it from

A. oheatora and from the further related A. magnasulcata,

A. magnasulcatissima and A. sulcata.

Etymology: This species is dedicated to Anne Fontaine, wife of the third author.

[FIGURE 5 approximately here]

\section{Australdonta sibleti sp. nov.}

Figures $3 \mathrm{C}, 6$, 14 $\mathrm{C}, 15 \mathrm{C}$

Examined material (137 specimens). Holotype: MNHN 25201, Rr8. Paratypes: MNHN 25202, 8 shells, Rr8. Additional material: 1 shell, Rr6; 1 shell, Rr20; 1 shell, Rr22; 32 shells, Rr31; 26 shells, Rr35; 7 shells, Rr36; 1 shell, Rr38; 11 shells, Rr42; 2 shells, Rr43; 1 shell, Rr53; 2 shells, Rr54; 2 shells, Rr57; 8 shells, Rr62; 32 shells, Rr66; 3 shells, Rr68.

Diagnosis: Shell with a flat apex and spire, rounded periphery, well-spaced primary axial ribs, without flammulations; teleoconch without spiral sculpture.

Description: Shell discoidal, white to light fawn, without markings. Shell thin, usually pellucid, rarely opaque; periostracum adherent, shiny. Apex and spire flat; last whorl descending more rapidly. Apical and umbilical sutures impressed; whorls rounded, periphery rounded to very weakly angled. Transition between protoconch and teleoconch indistinct. Protoconch sculptured by very fine, widely spaced spiral and axial lirae, forming a reticulated pattern; spiral lirae wobbly in aspect, fading on the transitional zone between protoconch and teleoconch. Axial lirae 
progressively transitioning into coarser ribs, constituting the primary sculpture of the teleoconch. Interspaces between primary ribs occupied by secondary sculpture of two to six wavy axial riblets. Umbilicus very wide, shallow. Peristome crescent-shaped. Palatal wall with two to four recessed traces, all usually very low, rarely with the second and third reaching the prominence of typical barriers; palatal traces/barriers extending approximately one-eighth whorl, with gradual anterior and posterior descension; first columellar in position, often lacking, slightly less prominent and a little more deeply recessed than second; second basal in position, slightly wider than the third, infraperipheral trace; forth often lacking, supraperipheral, a little more deeply recessed, slightly less prominent than third. Parietal barriers two to three in number, not recessed within aperture, extending inwards beyond the line of vision from the peristome, with gradual anterior descension; first and second higher posteriorly, invariably present; third often lacking, less prominent than remainder, approximately constant in height throughout its visible extent. Rarely with a trace between the second and third parietal barriers. Other shell features that can be expressed numerically are shown in Table 2.

Remarks: Endodontids commonly display flaking periostracal extensions of their shell sculpture (Solem 1976, p. 34). In A. raivavaeana Solem, 1976 (Solem 1976, fig. 23), periostracal lamellae project from the apexes of narrow shell ribs and riblets that closely resemble those of A. sibleti. However, periostracal extensions were not visible in scanning electron micrographs of any of the new species described herein. Given the similarity of the sculptural elements formed by the shell wall, it seems likely that $A$. sibleti, A. florencei and perhaps a few other of the new taxa established here may have displayed periostracal lamellae, which were not 
preserved in the dead shells available for examination.

In size, overall shape and coloration, A. sibleti most closely resembles A. pseudplanulata Solem, 1976, with which it occurs sympatrically.

However, the more spaced primary axial sculpture of $A$. sibleti readily and consistently distinguish it from A. pseudplanulata, even in juvenile material. Additionally, A. sibleti normally has palatal barriers that are much smaller and fewer than the four prominent palatal barriers of A. pseudplanulata. In A. sibleti, this latter arrangement was only found in specimens collected along the Northwest coast of Rurutu (stations Rr42, Rr43 and Rr57), and in one specimen from station Rr31, in the central East coast (Fig. 6E). Shell sculpture also seems to display some degree of geographical variation, with all A. sibleti collected in the Southwest of the island (station Rr62) and many collected in the most southern stations exhibiting weaker primary axial ribs. Variation in parietals was essentially in the number of barriers present, with one quarter of the examined material lacking the third barrier, and two specimens showing a trace between the second and third barriers. In other aspects all of these specimens agree well with typical A. sibleti; variations in shell sculpture and morphology of apertural barriers are thus presently regarded as intraspecific.

Superficially A. sibleti may also be mistaken for A. florencei-which displays a similar primary axial sculpture of well-spaced, narrow ribs-but that species lacks secondary axial sculpture in the late teleoconch, has prominent spiral ornamentation, a narrower umbilicus, a more elevated spire and axial ribs that are slightly denser and taller than those of $A$. sibleti.

Etymology: This species is dedicated to Jean-Philippe Siblet, head of the Natural Heritage Service of MNHN, eminent birder-nobody's perfect.

[FIGURE 6 approximately here] 


\section{Australdonta florencei sp. nov.}

Figures 3D, 7, 14D, 15D

Examined material (1732 specimens). Holotype: MNHN 25203, Rr4.

Paratypes: MNHN 25204, 8 shells, Rr38. Additional material: 58

shells, Rr19; 821 shells, Rr20; 11 shells, Rr21; 19 shells, Rr22; 1 shell, Rr30;

338 shells, Rr35; 14 shells, Rr36; 377 shells, Rr38; 5 shells, Rr40; 1 shell, Rr43; 23 shells, Rr52; 13 shells, Rr54; 54 shells, Rr66.

Diagnosis: Shell with a rounded periphery; teleoconch sculpture of spiral riblets and well-spaced axial ribs; palatal wall lacking barriers or displaying two to four traces.

Description: Shell depressed, white to light fawn; usually without markings, seldom with narrow, oblique or curved flammulations fading out towards the shell base. Shell thin, opaque to subpellucid; periostracum adherent, shiny. Apex flat to barely elevated; spire slightly to moderately raised, last whorl descending more rapidly. Apical and umbilical sutures impressed; whorls and periphery evenly rounded. Transition between protoconch and teleoconch indistinct. Protoconch ornamented by very fine, wobbly spiral lirae, forming a reticulated pattern with primary and secondary elements of axial sculpture. Primary axial sculpture present from the second whorl onwards, comprised of ribs that become coarser at the transitional zone between protoconch and teleoconch; primary ribs with interspaces four to eight times their width, persisting on the teleoconch. Secondary axial sculpture present from the nucleus approximately to the end of the second whorl, consisting of fine lirae that gradually transition into wavy riblets; secondary riblets with interspaces three to five times their width. Spiral sculpture of low to moderately prominent riblets, with 
interspaces two to four times their width, present from the third whorl onwards, occasionally forming minute nodules at intersections with axial ribs. Umbilicus wide, deep. Peristome crescent-shaped. Palatal wall usually with two or three barrier traces, rarely displaying four or lacking traces altogether; palatal traces similar in prominence, shallowly recessed, extending approximately one-sixteenth to one-eighth whorl, with gradual anterior and posterior descension; first and second basal in position; third infraperipheral, usually lacking. Parietal barriers usually three, less commonly two in number, not recessed within aperture, extending inwards a little less than one quarter whorl, with gradual anterior and posterior descension, gradually decreasing in prominence from the first to the third barrier; first and second barriers invariably present, third often lacking; first and third approximately constant in height throughout their extent; second higher posteriorly. Rarely with two traces between the second and third barriers. Other shell features that can be expressed numerically are shown in Table 2 ,

Remarks: A. florencei is somewhat variable in spire elevation, even though the apex is always flat or only barely elevated. The vast majority of examined specimens were similar to the holotype in having a slightly raised spire (Fig. 3D), but some were found with a considerably higher spire (Fig. 7E). Individuals with the spire almost flat are rare and resemble A. sibleti in shape. They can be distinguished from that species by the narrower, deeper umbilicus and conspicuous spiral ornamentation that characterize A. florencei. These same criteria, together with presence of palatal traces instead of barriers, easily separate $A$. florencei from the somewhat similar A. pseudplanulata.

Etymology: This species is dedicated to Jacques Florence, eminent 
botanist and delightful field companion.

[FIGURE 7 approximately here]

Australdonta pakalolo sp. nov.

Figures 8, 9, 14 F, 15A

Examined material (2 specimens). Holotype: MNHN 25195, Rr2.

Paratypes: MNHN 25196, 1 shell, Rr35.

Diagnosis: Shell light fawn, without flammulations; supraperipheral groove lacking or very shallow, developping from the fourth whorl onwards; primary and secondary axial sculpture of the teleoconch little differentiated; periphery angled; apertural barriers represented by traces (three to five parietals, zero to two palatals).

Description: Shell depressed to subdepressed, light fawn, without markings. Shell thin, opaque; periostracum adherent, shiny. Apex barely raised; spire barely to somewhat elevated; later whorls descending more rapidly. Apical suture impressed to canaliculate, umbilical suture impressed. Periphery weakly angled to acutely rounded; very shallow supraperipheral groove, when present, developing from the fourth whorl onwards. Transition between protoconch and teleoconch indistinct. Protoconch sculptured by fine, spiral and axial lirae; spiral lirae less prominent, fading on the transitional zone between protoconch and teleoconch. Axial lirae gradually transitioning into coarser, more crowded riblets, with interspaces two to four times their width, comprising the secondary axial sculpture of the teleoconch; primary axial sculpture of the teleoconch consisting of well spaced ribs, only slightly taller and wider than the secondary riblets, with 
interspaces approximately ten to twelve times their width. Umbilicus wide to very wide, moderately to very deep. Peristome ovate to trigonal-ovate. Palatal wall with or without two basal traces, slightly recessed within aperture, extending approximately one-eighth whorl, similar in prominence and width. Parietal barriers represented by three to five traces; first trace extending approximately one-quarter whorl or inwards beyond the line of vision from the peristome; all other traces extending inwards beyond the line of vision from the peristome; all but the fourth trace not recessed within aperture; fourth trace, when present, slightly recessed, much lower than remainder; first trace more prominent than the remainder; second trace, when present, equidistant from first and third traces; second, third and fifth traces similar in prominence and width. Other shell features that can be expressed numerically are shown in Table 2 .

Remarks: Only two specimens of A. pakalolo were recovered from distinct matos, and these display a number of morphological differences. The holotype has a barely elevated spire, a very shallow supraperipheral groove, weakly angled periphery, very wide umbilicus, palatal wall devoid of apertural barriers, and five barrier traces on the parietal wall. Conversely, the paratype is a relatively high shell, without supraperipheral groove, a trigonal outer wall, narrower umbilicus, two palatal and only three parietal traces. Additionally, the holotype appears to display a higher expansion rate of its helicocone, resulting in a larger aperture, and a slightly larger body size. Due to these differences we initially considered these specimens as representing two separate species. However, similarities in shell sculpture and in the morphology of the parietal barriers, as well as a reluctance to describe two species based on single specimens, led us to lump these shells under one highly variable species. They are, after all, more similar to one 
another than to any other known endodontid species. A critic re-evaluation of this hypothesis when more material surfaces is, of course, desirable.

The holotype of $A$. pakalolo shares with $A$. oheatora a very shallow supraperipheral groove and an ovate peristome constricted only by parietal traces. However, specimens of $A$. oheatora are much higher, have a deeper sulcus, a narrower umbilicus, a canaliculate, deeper apical suture, and display heavier axial sculpture with clearly distinguished primary ribs and secondary riblets. Reduced apertural barriers are also features of $A$. radiella (Pfeiffer, 1846) and A. radiella rurutuensis (Garrett, 1879), but these species differ from A. pakalolo in having a more rounded periphery, well-marked spiral striae on the teleoconch, sharply defined and much stronger axial sculpture, as well as regularly spaced flammulatioons, which persist even on eroded shells.

Etymology: Pakalolo is the Polynesian name for Cannabis sativa; the species was found on the ground of a plantation of this psychotic plant, hidden within the karstic, secluded mato. It is treated as a noun in apposition.

[FIGURE 8 approximately here]

[FIGURE 9 approximately here]

Australdonta teaae sp. nov.

Figures 10A, 11, 14E, 15E

Examined material (24 specimens). Holotype: MNHN 25205, Rr8. Paratypes: MNHN 25206, 8 shells, Rr8. Additional material: 3 shells, 
Rr8; 4 shells, Rr3; 3 shells, Rr4; 1 shell, Rr5; 1 shell, Rr46b; 2 shells, Rr61.

Diagnosis: Shell very large, much wider than high, with a long and narrow peripheral rostrum, devoid of a supraperipheral keel or groove.

Description: Shell discoidal, white, with reddish-brown flammulations on the apical surface, often faintly visible peripherally on the shell base through the subpellucid shell wall. Shell thin, opaque to subpellucid; periostracum adherent, matt. Apex and spire flat to moderately raised; later whorls descending more rapidly. Apical suture adpressed at apex, progressively deepening in subsequent whorls; umbilical suture impressed. Whorls strongly keeled peripherally, slightly to moderately concave in the vicinity of the keel, convex towards the shell axis. Transition between protoconch and teleoconch indistinct. Protoconch ornamented by fine spiral and axial lirae, forming a reticulated pattern. Spiral lirae persisting on the teleoconch. Axial lirae gradually transitioning into broader, very low ribs, with interspaces two to four times their width, comprising the primary axial sculpture of the teleoconch; secondary sculpture of the teleoconch formed by very fine, crowded axial riblets, with interspaces approximately equal to their width, overlaying the primary sculpture, and forming tiny nodules at intersections with spiral lirae. Umbilicus wide, shallow to moderately deep. Peristome elongated crescent, with rostrate periphery. Palatal wall with five shallowly recessed barriers, extending approximately one-eighth whorl, with gradual anterior and abrupt posterior descension; barriers one to four basal in position, regularly spaced, either similar in prominence or with the first barrier slightly lower than the remainder; barrier five supraperipheral, usually similar in prominence to the basal barriers, seldom trace-like. Parietal barriers three in number, regularly spaced, not recessed within 
aperture, with gradual anterior and abrupt posterior descension, extending approximately one-quarter whorl, decreasing in prominence slightly to markedly from the first to the third barrier. Other shell features that can be expressed numerically are shown in Table 2 .

Remarks: A. teaae displays great variability in spire elevation, umbilicus depth and angle of the peripheral rostrum. Isolated specimens may appear separable (Fig. $11 \mathrm{E}, \mathrm{F}$ ), but individuals exhibiting intermediate conditions suggest that only one species is involved. Specimens with a high spire (Fig. $11 \mathrm{E}$ ) approach A. collicella Zimmermann et al., 2009 in general shell shape. However, A. teaae may be readily distinguished from that species by its much longer peripheral rostrum and by the position of the apical suture, which adjoins the infraperipheral wall of the previous whorl in A. teaae, rather than connecting peripherally as in A. collicella. More typical specimens of A. teaae exhibit a low to very low spire (Figs 10A, 11F) and may superficially resemble A. magnasulcatissima, which shares a long peripheral rostrum and a similar arrangement of apertural barriers. However, the heavy sculpture, much wider umbilicus and the supraperipheral keel and groove of A. magnasulcatissima are unparalleled by A. teaae and provide easy and reliable criteria to distinguish these species. Recovered specimens of $A$. teaae were considerably worn, and many had large portions of the shell broken or missing; on average, shells of this species are more deteriorated than those of most other taxa described herein.

Etymology: This species is dedicated to Priscille Tea Frogier, head of the "Délégation à la Recherche" in Tahiti, in recognition for her involvement in this project and in the preservation of the "fenua".

[FIGURE 10 approximately here] 
[FIGURE 11 approximately here]

\author{
Genus Minidonta Solem, 1976 \\ Minidonta Solem, 1976: 126. Type species (by original designation): \\ Minidonta hendersoni Cooke \& Solem in Solem, 1976.
}

Minidonta boucheti sp. nov.

Figures $10 \mathrm{~B}, 12,14 \mathrm{G}, 15 \mathrm{~B}$

Examined material (47 specimens). Holotype: MNHN 25207, Rr68.

Paratypes: MNHN 25208, 8 shells, Rr68. Additional material: 11 shells, Rr68; 3 shells, Rr4; 13 shells, Rr8; 1 shell, Rr20; 1 shell, Rr30; 1 shell, Rr35; 3 shell, Rr42; 1 shell, Rr45; 4 shells, Rr57; 1 shell, Rr66.

Diagnosis: Shell with rounded periphery, coarse primary axial sculpture and prominent apertural barriers (five palatal barriers, rarely accompanied by one or two traces; four to six parietal barriers); umbilicus wider than one sixth of the diameter of the shell.

Description: Shell depressed, white, with or rarely without light to dark reddish-brown flammulations on the apical surface of the shell; flammulations usually fading out towards the shell base, less commonly persisting and transitioning to scattered, oblique markings. Shell thin, usually opaque, rarely subpellucid; periostracum adherent, matt. Apex flat to barely elevated, spire slightly to moderately raised, last whorl descending more rapidly. Apical and umbilical sutures impressed; whorls and periphery evenly rounded. Transition between protoconch and teleoconch indistinct. Protoconch sculptured by very fine spiral and axial lirae, forming a reticulated pattern; spiral lirae fading on the transitional zone between 
protoconch and teleoconch. Axial lirae progressively transitioning into coarse ribs, with interspaces three to four times their width, comprising the primary sculpture of the teleoconch. Secondary sculpture of the teleoconch formed by crowded axial riblets, with interspaces approximately equal to their width, overlaying the primary sculpture. Umbilicus wide, deep. Peristome crescent-shaped. Palatal wall with five prominent barriers and, rarely, one or two additional traces; barriers shallowly recessed, extending approximately one-eighth whorl, approximately regularly spaced, with gradual anterior and somewhat abrupt posterior descension; first to fourth barriers basal in position, similar in prominence; fifth barrier supraperipheral, slightly narrower and less prominent than the remainder. First palatal trace columellar in position, slightly more deeply recessed than barriers; second trace peripheral, positioned equidistantly between fourth and fifth barriers, slightly more deeply recessed than first trace, very low. Parietal barriers usually four, less commonly five or rarely six in number, with gradual anterior and abrupt posterior descension, gradually decreasing in prominence from the first to the fourth barrier; fifth and sixth barriers markedly less prominent than remainder. Barriers one to five not recessed within aperture; barrier six slightly recessed. Other shell features that can be expressed numerically are shown in Table 2 .

Remarks: Minidonta boucheti is sympatric with and resembles M. haplaenopla Solem, 1976 in size and shape, but is distinguished from that species by its coarser, more prominent primary axial sculpture, and by its larger number of apertural barriers. Diameter of the umbilicus provides the easiest and most reliable basis for separating $M$. boucheti and M. bieleri sp. nov.- it is wide in the former and very narrow in the latter species. Within the Austral Islands, species of Minidonta Solem, 1976 have been previously 
recorded only from Rurutu (M. haplaenopla) and Raivavae (five species). All display much narrower axial ribs than $M$. boucheti and $M$. bieleri, being hence readily distinguished. In addition, the five species from Raivavae may be separated from $M$. boucheti and $M$. bieleri using the following criteria: M. micraconica Solem, 1976 and M. gravacosta Solem, 1976 are much smaller and display a bifid first parietal barrier; M. anatonuana Solem, 1976 has narrower axial ribs, a higher apex and an umbilicus that is narrower than in $M$. boucheti but much wider than in M. bieleri; M. sulcata Solem, 1976 exhibits more crowded axial sculpture, reduced number of apertural barriers and wider umbilicus; and M. planulata Solem, 1976 is larger, more depressed and has a more rounded aperture.

Etymology: The species is dedicated to Philippe Bouchet, who introduced $\mathrm{OG}$ and $\mathrm{BF}$ to malacology and invited $\mathrm{AS}$ to participate in this work.

[FIGURE 12 approximately here]

\section{Minidonta bieleri sp. nov.}

Figures $10 \mathrm{C}, 13$, $14 \mathrm{H}, 15 \mathrm{~F}$

Examined material (4 specimens). Holotype: MNHN 25209, Rr8. Paratypes: MNHN 25210, 1 shell, Rr35; MNHN 25211, 2 shells, Rr66.

Diagnosis: Shell with rounded periphery, coarse primary axial sculpture and prominent apertural barriers (four barriers and three traces on palatal wall; five barriers on parietal); umbilicus very narrow (width less than one tenth of the diameter of the shell).

Description: Shell depressed, white, with dark reddish-brown, scattered 
flammulations on the apical surface and shell base. Shell thin, opaque; periostracum adherent, matt. Apex barely raised, spire elevated, later whorls descending more rapidly. Apical and umbilical sutures impressed; whorls and periphery rounded. Transition between protoconch and teleoconch indistinct. Protoconch sculptured by very fine spiral and axial lirae, forming a reticulated pattern; spiral lirae fading on the transitional zone between protoconch and teleoconch. Axial lirae progressively transitioning into coarse ribs, with interspaces two to four times their width, comprising the primary sculpture of the teleoconch. Secondary sculpture of the teleoconch formed by crowded, wavy axial riblets, with interspaces approximately equal to their width, overlaying the primary sculpture. Umbilicus very narrow, deep. Peristome crescent-shaped; columellar lip reflected towards the shell axis, constricting the umbilicus in part. Palatal wall with four barriers and three traces, all recessed, extending approximately one-eighth whorl, with gradual anterior and posterior descension; all traces deeply recessed; first trace columellar in position, second and third traces infraperipheral and peripheral in position; barriers regularly spaced, similar in prominence, progressively transitioning from very shallowly recessed (first) to deeply recessed (fourth barrier); first barrier positioned at the confluence of basal and columellar lips; second and third barriers mid-basal in position; fourth barrier positioned at the confluence of basal and peripheral walls, as deeply recessed as traces. Parietal barriers five in number, not recessed within aperture, extending approximately one-quarter whorl, regularly spaced, with gradual anterior and somewhat abrupt posterior descension; barriers one to four similar in morphology; fifth barrier lower than the remainder. Other shell features that can be expressed numerically are shown in Table 2.

Remarks: In overall shape, sculpture and coloration this species closely 
resembles $M$. boucheti, from which it is easily distinguished by its very narrow umbilicus. A relatively higher shell and a larger number of apertural barriers in $M$. bieleri appear to provide the most useful additional criteria for separation of these seemingly closely related species. For a comparison with Minidonta from Raivavae, refer to remarks under M. boucheti.

Etymology: The species is dedicated to Rüdiger Bieler, distinguished malacologist.

[FIGURE 13 approximately here]

[FIGURE 14 approximately here]

[Table 2 approximately here]

\section{Discussion}

The Mangarevan Expedition (Gregory 1935) represented the only previous surveying endeavour of the malacofauna of Rurutu before the recent effort by Gargominy \& Fontaine (2003; Table 3). Previous to the Mangarevan, only two species of Endodontidae had been described from Rurutu, both by Garrett (1879) based on a few specimens collected by Charles De Gage: Australdonta degagei (Garrett, 1879) and A. radiella rurutuensis. Solem (1976) discovered five more species in the material gathered by the Mangarevan expedition (A. magnasulcata, A. pseudplanulata, A. tapina Solem, 1976, A. yoshii Solem, 1976 and Minidonta haplaenopla), thus increasing the total number of described species to seven.

[Table 3 approximately here] 
Commenting on the comprehensiveness of the collections made under his lead, Cooke (in Gregory 1935, pp. 55-56) voiced his belief that few taxa, if any, may have passed unnoticed: "I consider that our landshell collections are nearly complete from most of the islands and that these need not be revisited... The destruction of forests on Mangareva, Rurutu, and Rimatara is already so complete that I think further study would add only a few species to those already taken by us". However, at least with regard to the endodontid fauna, Cooke could not have been further from the truth. Twelve species of the family were found in the material gathered by Gargominy \& Fontaine (2003), which had not been collected by the Mangarevan Expedition. Four of these species (A. collicella, A. magnasulcatissima, A. microspiralis Zimmermann et al., 2009 and A. sulcata) were formally described by Zimmermann et al. (2009) and the remaining eight are introduced here. Together, these studies take the number of known endodontid species of Rurutu from 7 to 19, i.e., almost a three-fold increase. Giving the diversity, high-endemism and low abundance of the endodontid fauna of Rurutu, future studies of unexplored parts of matos may reveal yet more species new to science.

\section{Geographic distribution}

The vast majority of the endodontid species from Rurutu seems to be endemic to the island; only one species, A. degagei, was previously recorded at single stations in Rimatara (Austral Islands) and Mauke (Cook Islands), where it may have been accidentally introduced (Solem 1976, p. 299). Most species were little abundant in the samples, about half being represented by less than 100 specimens (Table 3).

Within Rurutu, endodontids were not found in altitudes above $100 \mathrm{~m}$, and 
only three species (A. degagei, A. tapina and A. radiella rurutuensis) were recovered from stations in the degraded areas outside cliffs of raised coral reef (matos; Fig. 16). Similarly, it appears that all stations of the Mangarevan Expedition yielding endodontid shells were located in matos or at their immediate vicinity (Solem 1983, p. 287). This pattern is not surprising, because limestone outcrops are known to harbor a higher diversity and density of land snails than other types of substrata (e.g., Schilthuizen 2004; Fontaine et al. 2007). Moreover, in the case of the presumably extinct endodontid fauna of Rurutu (see discussion below), the isolation and better potential for post-mortem preservation of calcareous shells that characterizes limestone areas is also likely to play an important role in explaining the distributional pattern.

[FIGURE 15 approximately here]

[FIGURE 16 approximately here]

Recovery localities of each species (Figs 15, 16 A-G) show most taxa occurring in several matos. Only A. oheatora and A. magnasulcatissima are possibly restricted to Mato Toarutu and the Mato Toerau, from where 48 and 12 specimens of these species were recovered, respectively. Other taxa recorded from only one locality or within one mato were very rare in the samples, hence with a high probability that they may have been overlooked elsewhere. The general pattern suggests a low degree of isolation among the disjunct limestone outcrops.

Recorded endodontid species richness is higher on the east than on the west coast of Rurutu, with one station on the mato of Paparai and one on Mato Toarutu displaying the observed maximum of eleven species at a single station (Fig. 16H). However, more stations were concentrated on areas of 
raised coral reef on the east coast than on the west and, because sampling carried out by Gargominy \& Fontaine (2003) was qualitative, sampling efforts per station are not directly comparable. Paleoecological studies using quantitative methods would be required to test whether an east/west partition is a result of differential sampling effort and/or taphonomical differences among sites, or if it may be of biogeographical significance.

\section{Extinction}

When the team led by Cooke visited Rurutu in 1934, they found considerable environmental degradation and only two remnants of primary forest (Cooke in Gregory 1935). The report by Solem (1976) of A. degagei collected alive by the Mangarevan Expedition comprises the sole record of an endodontid snail extant in Rurutu. Although nearly eight thousand empty shells of A. degagei were collected by Gargominy \& Fontaine (2003), not a single living specimen of this species could be located, nor of any of the other endodontid taxa of Rurutu. The family is most probably extinct on the island, even though it is not possible to refute the idea that a few species may be represented by remnant populations inhabiting the deep crevices of the matos (Gargominy \& Fontaine 2003; Zimmermann et al. 2009).

No direct evidence of the timing and factors leading to the demise of the endodontid snails of Rurutu is presently available. However, considering what is known of the biology of endodontids, and of the history of human occupation of the island, a probable scenario may be outlined. With few exceptions, endodontids are restricted to zones of high humidity and only found on the ground stratum of primary forests (Solem 1976). Hence, destruction of their habitat by loss of primary vegetation probably played a major role in their extinction. 
Precise figures are not available, but it seems clear that reduction of the forest cover of Rurutu began with the initial colonization of the island by the Polynesians around the thirteenth century A.D., and that deforestation rates increased by the late fourteenth century as agriculture intensified and populations grew (Bollt 2008). Prehistoric Polynesian inhabitants also introduced to Rurutu animals that undoubtedly contributed to environmental degradation, including the pig (Sus scrofa), dog (Canis familiaris), chicken (Gallus gallus), and Pacific rat (Rattus exulans) (Steadman \& Bollt 2010). By the time of the first European contact, Rurutu had already suffered heavy deforestation, as evidenced by the account of Joseph Banks, naturalist aboard H.M.S. Endeavour, in August 1769: "The island of Oheteroa [Rurutu] was to all appearance more barren than anything we have seen in these seas..." (Banks 1869, p. 124). It seems reasonable to postulate that most endodontid species were probably extinct by that time.

Other factors commonly associated to extinctions of Pacific land snails, such as the introduction of predatory alien species, do not appear to have played a major role in this case. In particular, the North American carnivorous snail Euglandina rosea, identified as a major contributor to the extinction of the native malacofauna of Pacific islands (Murray et al. 1988; Griffiths et al. 1993), has not been introduced to Rurutu (Gargominy \& Fontaine 2003). West African Streptostele musaecola, another molluscivorous species, is present but very rare in Rurutu; nothing is known regarding the date of its introduction (Gargominy \& Fontaine 2003).

Solem (1976) postulated that predation of snail eggs and juveniles by introduced ants was an important factor in the eradication of endodontids from Oahu and Upolu, and possibly other islands. Thirty-two species of ants, whose dates of introduction are unknown, now inhabit Rurutu 
(Krushelnycky 2008; Wheeler 1936; Wilson \& Taylor 1967). Among these, Anoplolepis gracilipes was listed among 100 of the world's worst invasive species for its severe impact on terrestrial ecosystems (Lowe et al. 2000$)$, but its interaction with land snails is yet to be documented.

A more rigorous assessment of the timing and factors that contributed to the probable extinction of endodontids in Rurutu, both fundamental for drawing conservation plans for the remaining extant fauna, awaits taphonomic studies providing estimates of the average time empty shells may last in the calcareous sediments of the island. Very few investigations of shell decomposition in terrestrial settings have been carried out; the few attempted experiments indicate figures varying from a few months to several decades (Cadée 1999; Barrientos 2000; Pearce 2008). Because temperature, humidity, pH, insolation (Menez 2002) and biotic interactions are likely to play important roles, rates of shell decay may be radically different in distinct environments (Pearce 2008). Although quantitative data is lacking, calcareous settings such as the matos of Rurutu are known to yield good preservation (Evans 1972). Hence, the apparent freshness of some of the collected material does not provide enough grounds to refute the possibility of extinction.

Much of the malacofauna now extant in Rurutu comprise non-indigenous species, particularly subulinids (Gargominy \& Fontaine 2003). Introduction of wide-range invasive snails in Pacific islands, following or concomitant with extinction of endemic species, is a common phenomenon, which has progressively led to a homogenization of their faunas (Cowie 2001). The demise of the endodontids of Rurutu appears to be just one more example of the environmental crisis that has affected native land snail faunas throughout the Pacific Abdou \& Bouchet 2000; Bouchet \& Abdou 2001, 2003). 


\section{Acknowledgements}

This study is part of project LOSERS, funded by ANR "6"me extinction", and of project "Expédition scientifique aux Australes" of the program "Inventaire et Valorisation de la Biodiversité", funded by the "Délégation à la Recherche" of the government of French Polynesia, and the Institut Louis Malardé (Papeete, Tahiti). We thank Jean-Yves Meyer for organizing the biodiversity survey of the Austral Islands. The authors wish to thank Regina Kawamoto (Bernice P. Bishop Museum) for a loan of type specimens of Endodontidae. SEM was carried out at the MNHN, with assistance from Sylvain Pont. AS is grateful for the financial support of the Centre National de la Recherche Scientifique (CNRS).

\section{Literature Cited}

Abdou, A. \& Bouchet, P. (2000) Nouveaux gastéropodes Endodontidae et Punctidae (Mollusca, Pulmonata) récemment éteints de l'archipel des Gambier (Polynésie). Zoosystema, 22(4), 689-707.

Banks, J. (1869) In: J.D. Hooker (Ed.), Journal of the Right Hon. Sir Joseph Banks Bart., K.B., P.R.S. during Captain Cook's first voyage in H.M.S. Endeavour in 1768-71 to Terra del Fuego, Otahite, New Zealand, Australia, the Dutch East Indies, etc. Macmillan, London.

Barrientos, Z. (2000) Population dynamics and spatial distribution of the terrestrial snail Ovachlamys fulgens (Stylommatophora: Helicarionidae) in a tropical environment. Revista de Biología Tropical, 48(1), 71-87.

Bauman, S. (1996) Diversity and decline of land snails on Rota, Mariana Islands. American Malacological Bulletin, 12(1), 13-27. 
Bollt, R. (2008) Excavations in Peva Valley, Rurutu, Austral Islands (East Polynesia). Asian Perspectives, 47(1), 156-187.

Bouchet, P. \& Abdou, A. (2001) Recent extinct land snails (Euconulidae) from the Gambier Islands with remarkable apertural barriers. Pacific Science, 55(2), 121-127.

Bouchet, P. \& Abdou, A. (2003) Endemic land snails from the Pacific islands and the museum record: Documenting and dating the extinction of the terrestrial Assimineidae of the Gambier Islands. Journal of Molluscan Studies, 69(3), 165-170.

Cadée, G.C. (1999) Bioerosion of shells by terrestrial gastropods. Lethaia, $32(3), 253-260$.

Cowie, R.H. (1996) Pacific island land snails: Relationships, origins, and determinants of diversity. In: A. Keast \& S.E. Miller (Eds.), Origin and Evolution of Pacific Island Biotas, New Guinea to Eastern Polynesia: Patterns and Processes. SPB Academic Publishing, Amsterdam, pp. $347-372$.

Cowie, R.H. (2001) Decline and homogenization of Pacific faunas: The land snails of American Samoa. Biological Conservation, 99(2), 207-222.

Cowie, R.H. \& Robinson, A. (2003) The decline of native Pacific island faunas: Changes in status of the land snails of Samoa through the 20th Century. Biological Conservation, 110(1), 55-65.

Evans, J.G. (1972) Land Snails in Archaeology. Seminar Press, London, 436 pp. 
Fontaine, B., Gargominy, O. \& Neubert, E. (2007) Priority sites for conservation of land snails in Gabon: testing the umbrella species concept. Diversity and Distributions, 13(6), 725-734.

Gargominy, O. \& Fontaine, B. (2003) Inventaire des Mollusques Continentaux de l'Archipel des Australes - Deuxieme Partie: Tubuai et Rurutu, 10-30 Novembre 2003, Rapport de Mission. Muséum national d'Histoire naturelle, 1-49 pp.

Garrett, A. (1879) List of land shells inhabiting Rurutu, one of the Austral Islands, with remarks on their synonymy, geographical range, and descriptions of new species. Proceedings of the Academy of Natural Sciences of Philadelphia, 31, 17-30.

Gregory, H.E. (1935) Report of the director for 1934. Bernice P. Bishop Museum Bulletin, 133, 1-71.

Gregory, H.E. (1936) Report of the director for 1935. Bernice P. Bishop Museum Bulletin, 140, 1-52.

Griffiths, O., Cook, A. \& Wells, S.M. (1993) The diet of the introduced carnivorous snail Euglandina rosea in Mauritius and its implications for threatened island gastropod faunas. Journal of Zoology, 229(1), 79-89.

Hadley, A. (2010) CombineZP: Image stacking software. Available from: http://www.hadleyweb.pwp.blueyonder.co.uk (accessed 15 May 2012).

Krushelnycky, P. (2008) Survey of Ants of Rimatara, Rurutu and Raiatea, French Polynesia, December 2006. Report to Délégation à la Recherche, $21 \mathrm{pp}$. 
Lowe, S., Browne, M., Boudjelas, S. \& De Poorter, M. (2000) 100 of the Worlds Worst Invasive Alien Species; A selection from the Global Invasive Species Database. The Invasive Species Specialist Group (ISSG) a specialist group of the Species Survival Commission (SSC) of the World Conservation Union (IUCN), 12 pp.

Lydeard, C., Cowie, R.H., Ponder, W.F., Bogan, A.E., Bouchet, P., Clark, S.A., Cummings, K.S., Frest, T.J., Gargominy, O., Herbert, D.G., Hershler, R., Perez, K.E., Roth, B., Seddon, M., Strong, E.E. \& Thompson., F.G. (2004) The global decline of nonmarine mollusks. BioScience, 54(4), 321-330.

Menez, A. (2002) The degradation of land snail shells during the annual dry period in a Mediterranean climate. Iberus, 20(2), 73-79.

Meyer, J.Y. \& Claridge, E. (Eds.) (in press) Terrestrial Biodiversity of the Austral Islands, French Polynesia, Patrimoines Naturels. MNHN, Délégation à la Recherche, Papeete, Paris.

Murray, J., Murray, E., Johnson, M.S. \& Clarke, B. (1988) The extinction of Partula on Moorea. Pacific Science, 42(3-4), 150-153.

Pearce, T.A. (2008) When a snail dies in the forest, how long will the shell persist? Effect of dissolution and micro-bioerosion. American Malacological Bulletin, 26(1-2), 111-117.

Regnier, C., Fontaine, B. \& Bouchet, P. (2009) Not knowing, not recording, not listing: Numerous unnoticed mollusk extinctions. Conservation Biology, 23(5), 1214-1221.

Schilthuizen, M. (2004) Land snail conservation in Borneo: limestone 
outcrops act as arks. Journal of Conchology, Special Publication, 3, $149-154$.

Solem, A. (1976) Endodontoid Land Snails from Pacific Islands (Mollusca: Pulmonata: Sigmurethra). Part 1. Family Endodontidae. Field Museum of Natural History, Chicago, Illinois, 508 pp.

Solem, A. (1983) Endodontoid Land Snails from Pacific Islands (Mollusca: Pulmonata: Sigmurethra). Part 2. Families Punctidae and Charopidae, Zoogeography. Field Museum of Natural History, Chicago, Illinois, 336 pp.

Steadman, D.W. \& Bollt, R. (2010) Prehistoric birds from Rurutu, Austral Islands, East Polynesia. Pacific Science, 64(2), 315-325.

Wheeler, W.M. (1936) Ants from the Society, Austral, Tuamotu and Mangareva Islands. Occasional Papers of the Bernice Pauahi Bishop Museum of Polynesian Ethnology and Natural History, 12(18), 1-17.

Wilson, E.O. \& Taylor, R.W. (1967) The ants of Polynesia. Pacific Insects Monograph, 14, 1-109.

Zimmermann, G., Gargominy, O. \& Fontaine, B. (2009) Quatre espèces nouvelles d'Endodontidae (Mollusca, Pulmonata) éteints de Rurutu (Îles Australes, Polynésie Française). Zoosystema, 31(4), 791-805. 
Table 1. List of stations sampled in Rurutu, French Polynesia.

Station Description

Rr1 South of Matonaa $\left(22.44386^{\circ} \mathrm{S} ; 151.3477^{\circ} \mathrm{W}\right)$. Taro fields. Limestone, alt. 10 m. 19/12/2002, coll. Gargominy \& Fontaine.

Rr2 South of Mato Matonaa $\left(22.44198^{\circ} \mathrm{S} ; 151.34689^{\circ} \mathrm{W}\right)$. Large boulders piled at the foot of the cliff. Hibiscus sp., plantation of Cannabis sativa. Limestone, alt. 20 m. 19/12/2002, coll. Gargominy \& Fontaine.

Rr3 Between Moerai and Pointe Arei $\left(22.4543^{\circ} \mathrm{S} ; 151.33054^{\circ} \mathrm{W}\right)$. Foot of the cliff, with Hibiscus sp. and Pandanus sp. Limestone, alt. $10 \mathrm{~m}$. 17/11/2003, coll. Gargominy \& Fontaine.

Rr4 Summit of Mato Arei $\left(22.45646^{\circ} \mathrm{S} ; 151.32684^{\circ} \mathrm{W}\right)$. Small, narrow canyon with Hibiscus sp., Pandanus sp., Asplenium sp. and forest with coconut trees. Limestone, alt. 95 m. 17/11/2003, coll. Gargominy \& Fontaine.

Rr5 Mato Arei $\left(22.45607^{\circ} \mathrm{S} ; 151.32778^{\circ} \mathrm{W}\right)$. Foot of the cliff, with Hibiscus sp., Pandanus sp. and Asplenium sp. Limestone, alt. 50 m. 17/11/2003, coll. Gargominy \& Fontaine.

Rr6 Mato Arei $\left(22.45687^{\circ} \mathrm{S} ; 151.32423^{\circ} \mathrm{W}\right)$. Foot of the cliff, with Hibiscus sp. Limestone, alt. 10 m. 17/11/2003, coll. Gargominy \& Fontaine.

Rr7 East side of Mato Arei $\left(22.4602^{\circ} \mathrm{S} ; 151.32389^{\circ} \mathrm{W}\right)$. Foot of the cliff, with Hibiscus sp., Barringtonia sp. Limestone, alt. 15 m. 11/17/2003, coll. Gargominy \& Fontaine.

Rr8 South side of Mato Arei, north of Peva Iti $\left(22.46402^{\circ} \mathrm{S} ; 151.32479^{\circ} \mathrm{W}\right)$. Foot of the cliff, with Barringtonia sp. Limestone, alt. 15 m. 17/11/2003, coll. Gargominy \& Fontaine.

Rr9 South side of Mato Arei, Peva Iti river $\left(22.4649^{\circ} \mathrm{S} ; 151.32749{ }^{\circ} \mathrm{W}\right)$. River with slow current, alt. 10 m. 17/11/2003, coll. Gargominy \& Fontaine.

Rr10 Junction of the Mt Manureva trail with the transverse road $\left(22.46374^{\circ} \mathrm{S}\right.$; $\left.151.34439^{\circ} \mathrm{W}\right)$. Roadside grasses. Volcanique, alt. $170 \mathrm{~m} .18 / 11 / 2003$, coll. Gargominy \& Fontaine.

Rr11 Northwest side of the first pass Southwest of Mt Manureva $\left(22.46138^{\circ} \mathrm{S}\right.$; $\left.151.35985^{\circ} \mathrm{W}\right)$. Degraded forest with Lantana camara, Kalanchoe sp., Angiopteryx sp. and Glochidion sp. Volcanic, alt. 340 m. 18/11/2003, coll. Gargominy \& Fontaine.

Rr12 Hanging valley Southwest of Mt Taatioe $\left(22.46453^{\circ} \mathrm{S} ; 151.36193^{\circ} \mathrm{W}\right)$. Forest with Metrosideros sp., Angiopteryx sp. Volcanic, alt. $270 \mathrm{~m}$. 18/11/2003, coll. Gargominy \& Fontaine.

Rr13 Valley South of Mt Taatioe $\left(22.46345^{\circ} \mathrm{S} ; 151.35976^{\circ} \mathrm{W}\right)$. Rainforest with Cyathea sp., Cyrtandra sp. Volcanic, alt. 300 m. 18/11/2003, coll. Gargominy \& Fontaine.

Rr14 Valley of Ruahoina (East Mt Teape) $\left(22.46144^{\circ} \mathrm{S} ; 151.36635^{\circ} \mathrm{W}\right)$. Forest with Metrosideros sp., Cyathea sp., Angiopteryx sp. Volcanic, alt. 180 m. 18/11/2003, coll. Gargominy \& Fontaine. 
Table 1. continued

\begin{tabular}{ll} 
Station & \multicolumn{1}{c}{ Description } \\
\hline Rr15 & $\begin{array}{l}\text { Valley of Ruahoina (East Mt Teape) }\left(22.46165^{\circ} \mathrm{S} ; 151.36667^{\circ} \mathrm{W}\right) . \text { Stream } \\
\text { (slow current). Volcanic, alt. } 170 \mathrm{~m} .18 / 11 / 2003, \text { coll. Gargominy \& }\end{array}$ \\
& $\begin{array}{l}\text { Fontaine. } \\
\text { Rr16 }\end{array}$ \\
& $\begin{array}{l}\text { Valley of Ruahoina (East Mt Teape) }\left(22.46337^{\circ} \mathrm{S} ; 151.3679^{\circ} \mathrm{W}\right) . \text { Forest } \\
\text { with Hibiscus sp., Barringtonia sp., coconut trees, Angiopteryx sp. }\end{array}$ \\
& Volcanic, alt. $120 \mathrm{~m} .18 / 11 / 2003$, coll. Gargominy \& Fontaine.
\end{tabular}

Rr17 East side of the pass between Mts Manureva and Taatioe $\left(22.462^{\circ} \mathrm{S}\right.$; $\left.151.35854^{\circ} \mathrm{W}\right)$. Volcanic, alt. 340 m. 18/11/2003, coll. Percy, Gargominy \& Fontaine.

Rr18 East slope of the North ridge of Mt Manureva (22.45769 ${ }^{\circ} \mathrm{S} ; 151.35745$ $\left.{ }^{\circ} \mathrm{W}\right)$. Forest with Cyrtandra sp. Volcanic, alt. 250 m. 18/11/2003, coll. Percy, Gargominy \& Fontaine.

Rr19 South Itirama, mato south of Hauti $\left(22.49583^{\circ} \mathrm{S} ; 151.32506^{\circ} \mathrm{W}\right)$. Foot of limestone boulders, with Hibiscus sp., Pandanus sp. and Aleurites sp. Limestone, alt. 80 m. 19/11/2003, coll. Gargominy \& Fontaine.

Rr20 Paparai, South Hauti, West Anatataura $\left(22.50075^{\circ} \mathrm{S} ; 151.32813^{\circ} \mathrm{W}\right)$. Bottom of cliff, with banana trees, Macropiper sp. and Aleurites sp. Limestone, alt. 10 m. 19/11/2003, coll. Gargominy \& Fontaine.

Rr21 Paparai, south of Hauti, Southwest Anatataura $\left(22.50265^{\circ} \mathrm{S}\right.$; $\left.151.32934^{\circ} \mathrm{W}\right)$. Foot of cliff with limestone boulders, banana trees and Pandanus sp. Limestone, alt. 20 m. 19/11/2003, coll. Gargominy \& Fontaine.

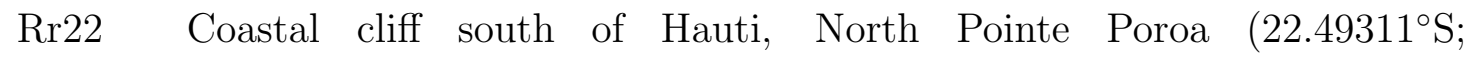
$\left.151.32392^{\circ} \mathrm{W}\right)$. Rocky slope with Pandanus sp. and Hibiscus sp. Limestone, alt. 20 m. 19/11/2003, coll. Gargominy \& Fontaine.

Rr23 Circular Road, Southeast Pointe Parari $\left(22.46613^{\circ} \mathrm{S} ; 151.36873^{\circ} \mathrm{W}\right)$. Hibiscus forest with Barringtonia sp. and Asplenium sp. Limestone, alt. 80 m. 20/11/2003, coll. Gargominy \& Fontaine.

Rr24 Circular road between Pointe Parari and Avera (22.46883 ${ }^{\circ}$; $\left.151.36574^{\circ} \mathrm{W}\right)$. Bottom of the cliff. Volcanic, alt. $120 \mathrm{~m}$. 20/11/2003, coll. Gargominy \& Fontaine.

Rr25 North entrance of the village of Avera $\left(22.4753^{\circ} \mathrm{S} ; 151.35458^{\circ} \mathrm{W}\right)$. Boulders by the sea. Limestone, alt. 2 m. 20/11/2003, coll. Gargominy \& Fontaine.

Rr26a South of Avera, Turiarata river $\left(22.48609^{\circ} \mathrm{S} ; 151.3483^{\circ} \mathrm{W}\right)$. Branch of stream diverted into a ditch. Volcanic, alt. 80 m. 20/11/2003, coll. Gargominy \& Fontaine.

Rr26b South of Avera, Turiarata river $\left(22.48609^{\circ} \mathrm{S} ; 151.3483^{\circ} \mathrm{W}\right)$. Seep bellow spring. Volcanic, alt. 80 m. 20/11/2003, coll. Gargominy \& Fontaine. 
Table 1. continued

\begin{tabular}{|c|c|}
\hline Station & Description \\
\hline $\operatorname{Rr} 27$ & $\begin{array}{l}\text { Southeast coast, Te Araroa }\left(22.51573^{\circ} \mathrm{S} ; 151.33379^{\circ} \mathrm{W}\right) \text {. Foot of cliff with } \\
\text { banana trees, Barringtonia sp., Pandanus sp. Limestone, alt. } 5 \mathrm{~m} \text {. } \\
\text { 20/11/2003, coll. Gargominy \& Fontaine. }\end{array}$ \\
\hline $\operatorname{Rr} 28$ & $\begin{array}{l}\text { Southeast coast, } 400 \mathrm{~m} \text { Northeast of Te Araroa }\left(22.51349^{\circ} \mathrm{S} \text {; }\right. \\
\left.151.33171^{\circ} \mathrm{W}\right) \text {. Rocky ledge on cliff with Pandanus sp. Limestone, alt. } \\
10 \mathrm{~m} .20 / 11 / 2003 \text {, coll. Gargominy \& Fontaine. }\end{array}$ \\
\hline
\end{tabular}

Rr29 Southeast coast, $800 \mathrm{~m}$ Northeast of Te Araroa $\left(22.51095^{\circ} \mathrm{S}\right.$; $151.32991^{\circ} \mathrm{W}$ ). Foot of the cliff (cave) with Pandanus sp. Limestone, alt. 10 m. 20/11/2003, coll. Gargominy \& Fontaine.

Rr30 South of Mato of Peva, Toerau cliff $\left(22.47156^{\circ} \mathrm{S} ; 151.32458^{\circ} \mathrm{W}\right)$. Foot of the cliff, with Hibiscus sp., Asplenium sp. and other ferns. Limestone, alt. 10 m. 21/11/2003, coll. Gargominy \& Fontaine.

Rr31 South of Mato of Peva, Toerau cliff $\left(22.47058^{\circ} \mathrm{S} ; 151.32522^{\circ} \mathrm{W}\right)$. Foot of the cliff with boulders, Barringtonia sp., Inocarpus fagifer, Hibiscus sp. and Pandanus sp. Limestone, alt. 15 m. 21/11/2003, coll. Gargominy \& Fontaine.

Rr32a Northeast of Mato of Peva $\left(22.46667^{\circ} \mathrm{S} ; 151.32383^{\circ} \mathrm{W}\right)$. Lower part of a small canyon descending from the plateau. Pandanus sp., Barringtonia sp., Hibiscus sp. Limestone, alt. 20 m. 21/11/2003, coll. Gargominy \& Fontaine.

Rr32b Northeast of Mato of Peva $\left(22.46667^{\circ} \mathrm{S} ; 151.32383^{\circ} \mathrm{W}\right)$. Lower part of a small canyon descending from the plateau. Fronds of Asplenium sp. Limestone, alt. 20 m. 21/11/2003, coll. Gargominy \& Fontaine.

Rr33 Lower valley of Peva Iti $\left(22.46448^{\circ} \mathrm{S} ; 151.32253^{\circ} \mathrm{W}\right)$. Hibiscus and Pandanus grove by the sea. Sandy soil, alt. 2 m. 21/11/2003, coll. Gargominy \& Fontaine.

Rr34 Village of Moerai $\left(22.45437^{\circ} \mathrm{S} ; 151.33505^{\circ} \mathrm{W}\right)$. Urban creek. Alt. $1 \mathrm{~m}$. 21/11/2003, coll. Englund, Gargominy \& Fontaine.

Rr35 South Paparai, east side of the valley $\left(22.50796^{\circ} \mathrm{S} ; 151.33548^{\circ} \mathrm{W}\right)$. Rocks in slope, with Barringtonia sp. Limestone, alt. 30 m. 22/11/2003, coll. Gargominy \& Fontaine.

Rr36 South Paparai, east side, slope rising above mato $\left(22.50772^{\circ} \mathrm{S}\right.$; $\left.151.33412^{\circ} \mathrm{W}\right)$. Rocky area with Pandanus sp., Barringtonia sp., Asplenium sp. Limestone, alt. 60 m. 22/11/2003, coll. Gargominy \& Fontaine.

Rr37 Paparai along the road between Itirama and Anatataura $\left(22.4975^{\circ} \mathrm{S}\right.$; $\left.151.32934^{\circ} \mathrm{W}\right)$. Ditch with Nymphea sp. surrounding a taro field. Alt. 20 m. 22/11/2003, coll. Gargominy \& Fontaine.

Rr38 North exit of the village of Hauti, foot of Mato Toarutu $\left(22.48491^{\circ} \mathrm{S}\right.$; $\left.151.32625^{\circ} \mathrm{W}\right)$. Rocky slope with Hibiscus sp. and Citrus sp. Limestone, alt. 5 m. 22/11/2003, coll. Gargominy \& Fontaine. 
Table 1. continued

Station Description

Rr39 Mato Toarutu, West slope, South of Pointe Mauo (below large cave) $\left(22.48062^{\circ} \mathrm{S} ; 151.3227^{\circ} \mathrm{W}\right)$. Rocky slope with Barringtonia sp. and Pandanus sp. Volcanic, alt. 15 m. 22/11/2003 , coll. Gargominy \& Fontaine.

Rr40 South Paparai, east side of the valley $\left(22.50378^{\circ} \mathrm{S} ; 151.33164^{\circ} \mathrm{W}\right)$. Foot of cliff with Hibiscus sp., Pandanus sp. and Elaeocarpus sp. Accumulation zone. Limestone, alt. 15 m. 22/11/2003, coll. Meyer, Gargominy \& Fontaine.

Rr41a Matonaa, coastal road, $100 \mathrm{~m}$ South of Anamaniania (22.44144 ${ }^{\circ} \mathrm{S}$; $\left.151.34621^{\circ} \mathrm{W}\right)$. Zone of fossil accumulation in limestone. Fairly compact matrix. Limestone, alt. 15 m. 23/11/2003, coll. Gargominy \& Fontaine.

Rr41b Matonaa, coastal road, $100 \mathrm{~m}$ South of Anamaniania $\left(22.44086^{\circ} \mathrm{S}\right.$; $\left.151.34629^{\circ} \mathrm{W}\right)$. Zone of fossil accumulation in limestone. Loose sand and shells. Limestone, alt. 15 m. 23/11/2003, coll. Gargominy \& Fontaine.

Rr42 Vitaria, Ana Ae'o ("Mitterrand" cave) $\left(22.44909^{\circ} \mathrm{S} ; 151.37345^{\circ} \mathrm{W}\right)$. Foot of cliff, degraded vegetation, banana trees, Hibiscus sp. Limestone, alt. 20 m. 23/11/2003, coll. Gargominy \& Fontaine.

Rr43 Vitaria, $100 \mathrm{~m}$ south of Ana Ae'o ("Mitterrand" cave) (22.44978 $\mathrm{S}$; $\left.151.37295^{\circ} \mathrm{W}\right)$. Foot of cliff, with Aleurites sp., banana and coconut trees. Limestone, alt. 40 m. 23/11/2003, coll. Gargominy \& Fontaine.

Rr44 West end of the transverse road, approximately $300 \mathrm{~m}$ from the coast, North side of the road $\left(22.47374^{\circ} \mathrm{S} ; 151.35099^{\circ} \mathrm{W}\right)$. Foot of cliff. Asplenium sp., Angiopteryx sp., Paraserianthes sp. Limestone, alt. 10 m. 23/11/2003, coll. Gargominy \& Fontaine.

Rr45 Shore south of Avera, between Pointe Terea and Pointe Teutu $\left(22.49367^{\circ} \mathrm{S} ; 151.35552^{\circ} \mathrm{W}\right)$. Foot of cliff, with Hibiscus sp. and Pandanus sp. Limestone, alt. 10 m. 23/11/2003, coll. Gargominy \& Fontaine.

Rr46a Pointe Arei, roadside $\left(22.45489^{\circ} \mathrm{S} ; 151.32446{ }^{\circ} \mathrm{W}\right)$. Solid fossiliferous matrix, between stalagmitic surfaces. Limestone, alt. 10 m. 23/11/2003, coll. Gargominy \& Fontaine.

Rr46b Pointe Arei, roadside $\left(22.45489^{\circ} \mathrm{S} ; 151.32446^{\circ} \mathrm{W}\right)$. Fossiliferous deposit in limestone matrix. Limestone, alt. 10 m. 23/11/2003, coll. Gargominy \& Fontaine.

Rr47 Valley Northeast of Mt Teape $\left(22.46095^{\circ} \mathrm{S} ; 151.3617^{\circ} \mathrm{W}\right)$. Degraded forest with Paraserianthes sp. Undergrowth of Macropiper sp., Angiopteryx sp., Cyathea sp. Volcanic, alt. 300 m. 24/11/2003, coll. Gargominy \& Fontaine.

Rr48 North ridge of Mt Manureva, West slope $\left(22.45954^{\circ} \mathrm{S} ; 151.35833^{\circ} \mathrm{W}\right)$. Paraserianthes sp. and Psidium sp. with residual Metrosideros sp. Dense undergrowth of Kalanchoe sp. Volcanic, alt. 320 m. 24/11/2003, coll. Gargominy \& Fontaine. 
Table 1. continued

Station

Description

Rr49 North ridge of Mt Manureva, West slope $\left(22.45694^{\circ} \mathrm{S} ; 151.35811^{\circ} \mathrm{W}\right)$.

Paraserianthes sp. with undergrowth of Cyathea sp., Angiopteryx sp. and Macropiper sp. Volcanic, alt. 300 m. 24/11/2003, coll. Gargominy \& Fontaine.

Rr50 Matonaa, South slope $\left(22.44266^{\circ} \mathrm{S} ; 151.34923^{\circ} \mathrm{W}\right)$. Foot of the cliff. Pandanus sp., Hibiscus sp., Lantana camara. Limestone, alt. $30 \mathrm{~m}$. 24/11/2003, coll. Gargominy \& Fontaine.

Rr51 Matonaa, South slope $\left(22.44169^{\circ} \mathrm{S} ; 151.34766^{\circ} \mathrm{W}\right)$. Foot of the cliff. Hibiscus sp., Pandanus sp. Limestone, alt. 20 m. 24/11/2003, coll. Gargominy \& Fontaine.

Rr52 South Paparai, east of the road $\left(22.51247^{\circ} \mathrm{S} ; 151.33572^{\circ} \mathrm{W}\right)$. Bottom of valley, forest with Hibiscus sp., Inocarpus sp. and coffee trees in the undergrowth. Limestone, alt. 80 m. 25/11/2003, coll. Gargominy \& Fontaine.

Rr53 Southwest coast, approximately $1 \mathrm{~km}$ from Pointe Toataratara, east of the road $\left(22.51851^{\circ} \mathrm{S} ; 151.34696^{\circ} \mathrm{W}\right)$. Foot of cliff, plantation (banana trees, taros). Limestone, alt. 40 m. 25/11/2003, coll. Gargominy \& Fontaine.

Rr54 Southeast coast, $1 \mathrm{~km}$ northeast of Te Araroa $\left(22.50811^{\circ} \mathrm{S} ; 151.3286^{\circ} \mathrm{W}\right)$. Foot of cliff, with Hibiscus sp. and Barringtonia sp. Limestone, alt. 10 m. 25/11/2003, coll. Gargominy \& Fontaine.

Rr55 Southwest coast, approximately $900 \mathrm{~m}$ of Toataratara Point, East of the road $\left(22.52065^{\circ} \mathrm{S} ; 151.34751^{\circ} \mathrm{W}\right)$. Rocks in Barringtonia forest. Limestone, alt. 10 m. 25/11/2003, coll. Gargominy \& Fontaine.

Rr56 South Narui $\left(22.51259^{\circ} \mathrm{S} ; 151.3463^{\circ} \mathrm{W}\right)$. Old coconut plantation, Paraserianthes sp., Hibiscus sp. Volcanic, alt. 60 m. 25/11/2003, coll. Gargominy \& Fontaine.

Rr57 Unaa, $200 \mathrm{~m}$ south of the airport buildings $\left(22.43499^{\circ} \mathrm{S} ; 151.3683^{\circ} \mathrm{W}\right)$. Rocks with Hibiscus sp., Barringtonia sp. and Asplenium sp. Limestone, alt. 5 m. 26/11/2003, coll. Gargominy \& Fontaine.

Rr58a Valley of Te Vaavai $\left(22.4383^{\circ} \mathrm{S} ; 151.37106^{\circ} \mathrm{W}\right)$. Fronds of Angiopteryx sp. in Hibiscus forest. Limestone, alt. 40 m. 26/11/2003, coll. Gargominy \& Fontaine.

Rr58b Valley of Te Vaavai $\left(22.4383^{\circ} \mathrm{S} ; 151.37106^{\circ} \mathrm{W}\right)$. Accumulation areas at the foot of cliff, in Hibiscus forest. Limestone, alt. 40 m. 26/11/2003, coll. Gargominy \& Fontaine.

Rr59 Valley of Te Vaavai $\left(22.4385^{\circ} \mathrm{S} ; 151.37074^{\circ} \mathrm{W}\right)$. Enlarged bed of torrent, weak current. On dead leaves and submerged stones. Limestone, alt. 45 m. 26/11/2003, coll. Gargominy \& Fontaine. 
Table 1. continued

Station Description

Rr60 $400 \mathrm{~m}$ Southeast of Pointe Parari $\left(22.46655^{\circ} \mathrm{S} ; 151.37047^{\circ} \mathrm{W}\right)$. Rocky coastline. Hibiscus sp. Limestone, alt. 5 m. 26/11/2003, coll. Gargominy \& Fontaine.

Rr61 Cliff between Avarua pass and Pointe Arei $\left(22.455^{\circ} \mathrm{S} ; 151.3272^{\circ} \mathrm{W}\right)$. Foot of cliff with Hibiscus sp. and Morinda sp. Limestone, alt. $30 \mathrm{~m}$. 26/11/2003, coll. Gargominy \& Fontaine.

Rr62 South of mato of Pointe Teutu $\left(22.5037^{\circ} \mathrm{S} ; 151.35383^{\circ} \mathrm{W}\right)$. Foot of cliff, $100 \mathrm{~m}$ from the beach, with Hibiscus sp. and Pandanus sp. Limestone, alt. 10 m. 27/11/2003, coll. Gargominy \& Fontaine.

Rr63 Te Araoeva, South of Teutu Point $\left(22.50134^{\circ} \mathrm{S} ; 151.356^{\circ} \mathrm{W}\right)$. Foot of the cliff by the sea. Barringtonia sp. Limestone, alt. 5 m. 27/11/2003, coll. Gargominy \& Fontaine.

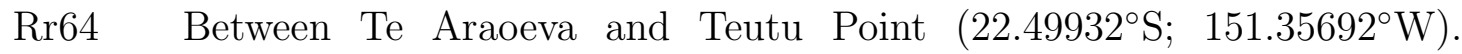
Isolated coastal patch of Pandanus sp. and Hibiscus sp., below cliff. Limestone, alt. 10 m. 27/11/2003, coll. Gargominy \& Fontaine.

Rr65 Narui, Avera road. Valley of Oroavaru $\left(22.50375^{\circ} \mathrm{S} ; 151.34602^{\circ} \mathrm{W}\right)$. Rocky slope with Barringtonia sp. Volcanic, alt. 90 m. 27/11/2003, coll.Gargominy \& Fontaine.

Rr66 East Mato Toarutu $\left(22.47973^{\circ} \mathrm{S} ; 151.32449^{\circ} \mathrm{W}\right)$. Boulders at the foot of the cliff, above plantation, Hibiscus sp. Limestone, alt. $30 \mathrm{~m}$. 28/11/2003, coll. Gargominy \& Fontaine.

Rr67 North Mato Toarutu, under a section of cliff that had collapsed $\left(22.47737^{\circ} \mathrm{S} ; 151.32312^{\circ} \mathrm{W}\right)$. Foot of the cliff. Limestone, alt. $45 \mathrm{~m}$. 28/11/2003, coll. Gargominy \& Fontaine.

Rr68 North Mato Toarutu, cave. Traditional harvesting area of helicinid shells for necklace handicraft $\left(22.47749^{\circ} \mathrm{S} ; 151.32232^{\circ} \mathrm{W}\right)$. Accumulation zone between cliff and small peak. Limestone, alt. 45 m. 28/11/2003, coll. Gargominy \& Fontaine.

Rr69 Peva, Maperevaru $\left(22.47415^{\circ} \mathrm{S} ; 151.32291^{\circ} \mathrm{W}\right)$. Rocks at the foot of the cliff, Hibiscus sp. Limestone, alt. 10 m. 28/11/2003, coll. Gargominy \& Fontaine.

Rr70 Puputa waterfall, West of Moerai $\left(22.45041^{\circ} \mathrm{S} ; 151.3521^{\circ} \mathrm{W}\right)$. Waterfall. Alt. 80 m. 27/11/2003, coll. Englund, Gargominy \& Fontaine. 
Table 2. Dimensions (in $\mathrm{mm}$ ) and ratios of type specimens. See Figure 2 for the placement of measurements. Tildes $(\sim)$ and dashes $(-)$ indicate approximate values and data missing due to poor preservation, respectively. Abbreviations: ah, aperture height; aw, aperture width; d, shell diameter; $\mathrm{h}$, shell height; nr, number of ribs on body whorl; sp, spire protrusion; $\mathrm{u}$, diameter of umbilicus; wn, number of whorls.

\begin{tabular}{|c|c|c|c|c|c|c|c|c|c|c|c|c|}
\hline Specimen & $\mathrm{d}$ & wn & $\mathrm{nr}$ & $\mathrm{h}$ & ah & aw & $\mathrm{sp}$ & $\mathrm{u}$ & $\mathrm{h} / \mathrm{d}$ & ah/aw & $\mathrm{u} / \mathrm{d}$ & $\mathrm{sp} / \mathrm{h}$ \\
\hline \multicolumn{13}{|l|}{ A. oheatora sp. nov. } \\
\hline holotype & 2.57 & 3.95 & 30 & 1.43 & 0.79 & 1.05 & 0.35 & 0.65 & 0.56 & 0.75 & 0.25 & 0.25 \\
\hline paratype 1 & 2.93 & 4.16 & 36 & 1.50 & 0.90 & 1.13 & 0.30 & 0.84 & 0.51 & 79 & 0.29 & 0.20 \\
\hline paratype 2 & 2.79 & 4.31 & 38 & 1.53 & 0.88 & 1.02 & 0.36 & 0.76 & 0.55 & 0.86 & 0.27 & 0.23 \\
\hline paratype 3 & 2.67 & 3.80 & 35 & 1.33 & 0.74 & 1.07 & 0.25 & 0.62 & 0.50 & 0.69 & 0.23 & 0.19 \\
\hline paratype 4 & 2.71 & 3.91 & 32 & 1.37 & 0.75 & 1.05 & 0.31 & 0.70 & 0.51 & 0.72 & 0.26 & 0.23 \\
\hline paratype 5 & 2.47 & 3.87 & 28 & 1.33 & 0.77 & 1.07 & 0.27 & 0 & 0.54 & & 20 & 0.20 \\
\hline paratype 6 & 2.64 & 3.88 & 30 & 1.37 & 0.78 & 1.03 & 0.34 & 0.53 & 0.52 & & 0.20 & 0.25 \\
\hline paratype 7 & 2.55 & 3.79 & 35 & 1.30 & 0.70 & 1.01 & 0.31 & 0.67 & 0.51 & 9 & 0.26 & 0.24 \\
\hline paratype 8 & 2.61 & 3.67 & 33 & 1.18 & 0.86 & 1.02 & 16 & & 0.45 & & .23 & 0.13 \\
\hline mean & 2.66 & 3.93 & 33.00 & 1.37 & 0.80 & 1.05 & 0.29 & 0.65 & 0.52 & & 0.24 & 0.21 \\
\hline standard deviation & 0.14 & 0.20 & 3.28 & 0.11 & 0.07 & 0.04 & 0.06 & 0.11 & 0.03 & 0.06 & 0.03 & 0.04 \\
\hline \multicolumn{13}{|l|}{ A. anneae sp. nov. } \\
\hline holotype & 3.30 & 4.15 & 36 & 1.41 & 0.92 & 1.27 & 0.38 & 0.86 & 0.43 & 0.73 & 0.26 & 0.27 \\
\hline paratype 1 & 2.72 & 3.58 & 33 & 1.08 & 0.74 & 0.95 & 0.33 & 0.79 & 0.40 & 0 . & 0.29 & 0.30 \\
\hline paratype 2 & 2.45 & 3.78 & - & 0.98 & 0.57 & 0.92 & 0.27 & 0.69 & 0.40 & 0.63 & 0.28 & 0.28 \\
\hline mean & 2.82 & 3.84 & 34.50 & 1.16 & 0.75 & 1.04 & 0.33 & 0.78 & 0.41 & 0 . & 0.28 & 0.28 \\
\hline standard deviation & 0.43 & 0.29 & 2.12 & 0.22 & 0.18 & 0.19 & 0.06 & 0.08 & 0.01 & 0.08 & 0.02 & 0.01 \\
\hline \multicolumn{13}{|l|}{ A. sibleti sp. nov. } \\
\hline holotype & 3.01 & 4.1 & 5 & 1.26 & 1.08 & 1.21 & 0.00 & 0.93 & 0.42 & 9 & 0.31 & 0.00 \\
\hline paratype 1 & 3.10 & 4.53 & 51 & 1.31 & 1.06 & 1.11 & 0.00 & 1.14 & 0.42 & 0.96 & 0.37 & 0.00 \\
\hline paratype 2 & 3.22 & 4.33 & 49 & 1.41 & 1.11 & 1.11 & & 1.16 & 0.44 & & 0.36 & 0.00 \\
\hline paratype 3 & 3.06 & - & - & 1.33 & 1.06 & 1.11 & 0.00 & 1.04 & 0.44 & 0.96 & 0.34 & 0.00 \\
\hline paratype 4 & 3.11 & 4.3 & 52 & 1.28 & 0.99 & 1.04 & 0.00 & 1.04 & 0.41 & 0. & 0.33 & 0.00 \\
\hline paratype 5 & 2.75 & 4.17 & 47 & 1.16 & 0.96 & 0.99 & 0.00 & 0.94 & 0.42 & 0.98 & 0.34 & 0.00 \\
\hline paratype 6 & 3.00 & 4.09 & 44 & 1.19 & 1.04 & 1.06 & 0.00 & 0.96 & 0.39 & 0.98 & 0.32 & 0.00 \\
\hline paratype 7 & 2.75 & 4.00 & 47 & 1.11 & 0.96 & 0.96 & 0.00 & 0.89 & 0.40 & 1.00 & 0.32 & 0.00 \\
\hline paratype 8 & 2.50 & 3.74 & 39 & 0.99 & 0.99 & 0.86 & 0.00 & 0.81 & 0.39 & 1.14 & 0.33 & 0.00 \\
\hline mean & 2.95 & 4.17 & 48.12 & 1.23 & 1.03 & 1.05 & & 0.99 & 0.42 & 0.98 & 0.34 & 0.00 \\
\hline standard deviation & 0.23 & 0.24 & 5.19 & 0.13 & 0.05 & 0.10 & 0.00 & 0.11 & 0.02 & 0.07 & 0.02 & 0.00 \\
\hline
\end{tabular}


Table 2. continued

\begin{tabular}{|c|c|c|c|c|c|c|c|c|c|c|c|c|}
\hline Specimen & $\mathrm{d}$ & wn & $\mathrm{nr}$ & $\mathrm{h}$ & ah & aw & $\mathrm{sp}$ & $\mathrm{u}$ & $\mathrm{h} / \mathrm{d}$ & $\mathrm{ah} / \mathrm{aw}$ & $\mathrm{u} / \mathrm{d}$ & $\mathrm{sp} / \mathrm{h}$ \\
\hline \multicolumn{13}{|l|}{ A. florencei sp. nov. } \\
\hline holotype & 3.62 & 4.53 & 57 & 1.60 & 1.36 & 1.50 & 0.14 & 0.86 & 0.44 & 0.90 & 0.24 & 0.08 \\
\hline paratype 1 & 3.55 & 5.04 & 66 & 1.83 & 1.15 & 1.40 & 0.12 & 0.82 & 0.52 & .82 & 0.23 & 0.06 \\
\hline paratype 2 & 3.39 & 4.95 & 58 & 1.78 & 1.13 & 1.25 & 0.20 & 0.90 & 0.52 & 0.91 & 0.26 & 0.11 \\
\hline paratype 3 & 3.38 & 4.78 & 60 & 1.70 & 1.17 & 1.27 & 0.16 & 1.00 & 0.50 & 0.92 & 0.29 & 0.09 \\
\hline paratype 4 & 3.45 & 4.86 & 64 & 1.72 & 1.07 & 1.37 & 0.14 & 0.88 & 0.50 & & 25 & 0.08 \\
\hline paratype 5 & 3.36 & 4.49 & 60 & 1.60 & 1.25 & 1.35 & 0.08 & 0.94 & & & .28 & 0.05 \\
\hline paratype 6 & 2.91 & 4.46 & 57 & 1.64 & 1.09 & 1.29 & 0.10 & 0.74 & 0.56 & 0 & 0.25 & 0.06 \\
\hline paratype 7 & 2.94 & 4.57 & 49 & 1.91 & 1.11 & 1.17 & 0.16 & 0.78 & 0.65 & & .27 & 0.08 \\
\hline parat & 2.73 & 4.08 & 52 & 2.03 & 1.05 & 1.13 & 0 & 0.70 & 4 & & .26 & 0.00 \\
\hline mean & 3.26 & 4.64 & & 1.76 & & & & & & & 26 & 0.07 \\
\hline standard deviation & 0.32 & 0.30 & 5.33 & 0.15 & 0.10 & 0.12 & 0.06 & 0.09 & 0.09 & 0.06 & 0.02 & 0.03 \\
\hline \multicolumn{13}{|l|}{ A. pakalolo sp. nov. } \\
\hline par & 2.38 & 4.40 & & 1.51 & 0 & & & & & & .25 & 0.27 \\
\hline mean & 2.73 & 4.12 & 32.50 & 1.44 & 0.82 & 1.13 & 0.29 & 0.75 & 0.54 & 0 & 0.27 & 0.20 \\
\hline standard deviation & 0.49 & 0.49 & 6.36 & 0.11 & 0.18 & 0.23 & 0.19 & 0.21 & 0.14 & 0.01 & 0.03 & 0.10 \\
\hline \multicolumn{13}{|l|}{ A. teaae sp. nov. } \\
\hline holotype & 6.03 & 5.26 & $\sim 256$ & 1.57 & 1.02 & 2.28 & 0.51 & 1.29 & .26 & 0.45 & 0.21 & 0.32 \\
\hline paratype 1 & 5.87 & 5.52 & $\sim 212$ & 2.29 & 1.20 & 3.14 & 0.92 & 1.24 & 0.39 & 8 & 0.21 & 0.40 \\
\hline paratype 2 & 5.76 & 4.86 & & 1.68 & & & & 1.39 & 0.29 & & 0.24 & 0.15 \\
\hline paratype 3 & 5.53 & 4.70 & $\sim 192$ & 1.29 & 1.03 & 2.19 & 0.23 & 1.28 & 0.23 & 0.47 & 0.23 & 0.18 \\
\hline paratype 4 & 5.52 & 5.15 & $\sim 196$ & 1.72 & 0.88 & 2.20 & 0.93 & 1.13 & 0.31 & & 0.20 & 0.54 \\
\hline paratype 5 & 5.08 & 4.66 & $\sim 216$ & 1.15 & 0.85 & 2.15 & 0.39 & 1.13 & 0.23 & 0.40 & 0.22 & 0.34 \\
\hline paratype 6 & 3.84 & 3.92 & $\sim 140$ & 0.86 & 0.78 & 1.64 & 0.20 & 0.88 & 0.22 & 0.48 & 0.23 & 0.23 \\
\hline paratype 7 & 3.98 & 3.06 & $\sim 152$ & 0.98 & 0.77 & 1.65 & 0.20 & 0.87 & 0.25 & 0.47 & 0.22 & 0.21 \\
\hline paratype 8 & 5.87 & 5.27 & $\sim 260$ & - & 1.06 & 2.14 & - & 1.33 & - & 0.49 & 0.23 & - \\
\hline mean & 5.28 & 4.71 & 203.11 & 1.44 & 0.99 & 2.23 & 0.45 & 1.17 & 0.27 & 0.45 & 0.22 & 0.30 \\
\hline standard deviation & 0.82 & 0.78 & 40.39 & 0.47 & 0.19 & 0.47 & 0.31 & 0.19 & 0.06 & 0.04 & 0.01 & 0.13 \\
\hline
\end{tabular}


Table 2. continued

\begin{tabular}{lcccccccccccc} 
Specimen & $\mathrm{d}$ & $\mathrm{wn}$ & $\mathrm{nr}$ & $\mathrm{h}$ & $\mathrm{ah}$ & $\mathrm{aw}$ & $\mathrm{sp}$ & $\mathrm{u}$ & $\mathrm{h} / \mathrm{d}$ & $\mathrm{ah} / \mathrm{aw}$ & $\mathrm{u} / \mathrm{d}$ & $\mathrm{sp} / \mathrm{h}$ \\
\hline $\begin{array}{l}\text { M. boucheti sp. nov. } \\
\text { holotype }\end{array}$ & 3.10 & 5.66 & 86 & 1.48 & 0.83 & 1.13 & 0.42 & 0.80 & 0.48 & 0.73 & 0.26 & 0.28 \\
paratype 1 & 3.33 & 6.04 & 83 & 1.95 & 0.94 & 1.21 & 0.80 & - & 0.59 & 0.78 & - & 0.41 \\
paratype 2 & 3.14 & 5.52 & 84 & 1.57 & 0.89 & 1.23 & 0.37 & 0.79 & 0.50 & 0.72 & 0.25 & 0.24 \\
paratype 3 & 2.85 & 5.35 & 84 & 1.51 & 0.86 & 1.19 & 0.43 & 0.56 & 0.53 & 0.73 & 0.20 & 0.29 \\
paratype 4 & 2.80 & 5.29 & 94 & 1.38 & 0.90 & 0.99 & 0.31 & 0.78 & 0.49 & 0.91 & 0.28 & 0.22 \\
paratype 5 & 2.64 & 4.81 & 67 & 1.26 & 0.79 & 1.04 & 0.19 & 0.62 & 0.48 & 0.76 & 0.23 & 0.15 \\
paratype 6 & 2.73 & 4.72 & 73 & 1.25 & 0.77 & 1.12 & 0.25 & 0.57 & 0.46 & 0.68 & 0.21 & 0.20 \\
paratype 7 & 2.66 & 4.35 & 66 & 1.27 & 0.77 & 1.09 & 0.32 & 0.64 & 0.48 & 0.70 & 0.24 & 0.25 \\
paratype 8 & 2.43 & 4.89 & 67 & 1.02 & 0.80 & 0.93 & 0.15 & 0.60 & 0.42 & 0.87 & 0.25 & 0.14 \\
mean & 2.85 & 5.18 & 78.22 & 1.41 & 0.84 & 1.10 & 0.36 & 0.67 & 0.49 & 0.76 & 0.24 & 0.24 \\
standard deviation & 0.29 & 0.53 & 10.17 & 0.26 & 0.06 & 0.10 & 0.19 & 0.10 & 0.05 & 0.08 & 0.03 & 0.08 \\
& & & & & & & & & & & & \\
M. bieleri sp. nov. & & & & & & & & & & & & \\
holotype & 3.18 & 5.75 & 74 & 1.64 & 0.99 & 1.45 & 0.30 & 0.26 & 0.51 & 0.68 & 0.08 & 0.18 \\
paratype 1 & 2.58 & 5.03 & 68 & 1.43 & 0.75 & 1.21 & 0.37 & 0.07 & 0.56 & 0.62 & 0.03 & 0.26 \\
paratype 2 & 2.84 & 5.48 & 79 & 1.66 & 0.90 & 1.27 & 0.44 & 0.20 & 0.58 & 0.71 & 0.07 & 0.27 \\
paratype 3 & 3.19 & 5.01 & 94 & 1.82 & 1.05 & 1.63 & 0.55 & 0.04 & 0.57 & 0.64 & 0.01 & 0.30 \\
mean & 2.95 & 5.32 & 78.8 & 1.64 & 0.92 & 1.39 & 0.41 & 0.14 & 0.56 & 0.66 & 0.05 & 0.25 \\
standard deviation & 0.30 & 0.36 & 11.1 & 0.16 & 0.13 & 0.19 & 0.11 & 0.11 & 0.03 & 0.04 & 0.03 & 0.05
\end{tabular}


Table 3. Number of specimens of Endodontidae collected by the Mangarevan Expedition (1934) and by Gargominy \& Fontaine (2003) in Rurutu. Data from Zimmermann et al. (2009), supplemented here.

\begin{tabular}{lrr} 
Species & 1934 & 2003 \\
\hline Australdonta degagei (Garrett, 1879) & 275 & 7948 \\
Australdonta tapina Solem, 1976 & 112 & 3472 \\
Australdonta pseudplanulata Solem, 1976 & 15 & 2687 \\
Australdonta florencei sp. nov. & - & 1732 \\
Australdonta collicella Zimmermann et al., 2009 & - & 297 \\
Australdonta magnasulcata Solem, 1976 & 5 & 159 \\
Australdonta sibleti sp. nov. & - & 137 \\
Australdonta radiella rurutuensis (Garrett, 1879) & - & 126 \\
Australdonta yoshii Solem, 1976 & 115 & 116 \\
Australdonta microspiralis Zimmermann et al., 2009 & - & 115 \\
Australdonta oheatora sp. nov. & - & 48 \\
Minidonta boucheti sp. nov. & - & 47 \\
Minidonta haplaenopla Solem, 1976 & 77 & 43 \\
Australdonta teaae sp. nov. & - & 24 \\
Australdonta magnasulcatissima Zimmermann et al., 2009 & - & 18 \\
Australdonta sulcata Zimmermann et al., 2009 & - & 10 \\
Minidonta bieleri sp. nov. & - & 4 \\
Australdonta anneae sp. nov. & - & 3 \\
Australdonta pakalolo sp. nov. & - & 2
\end{tabular}




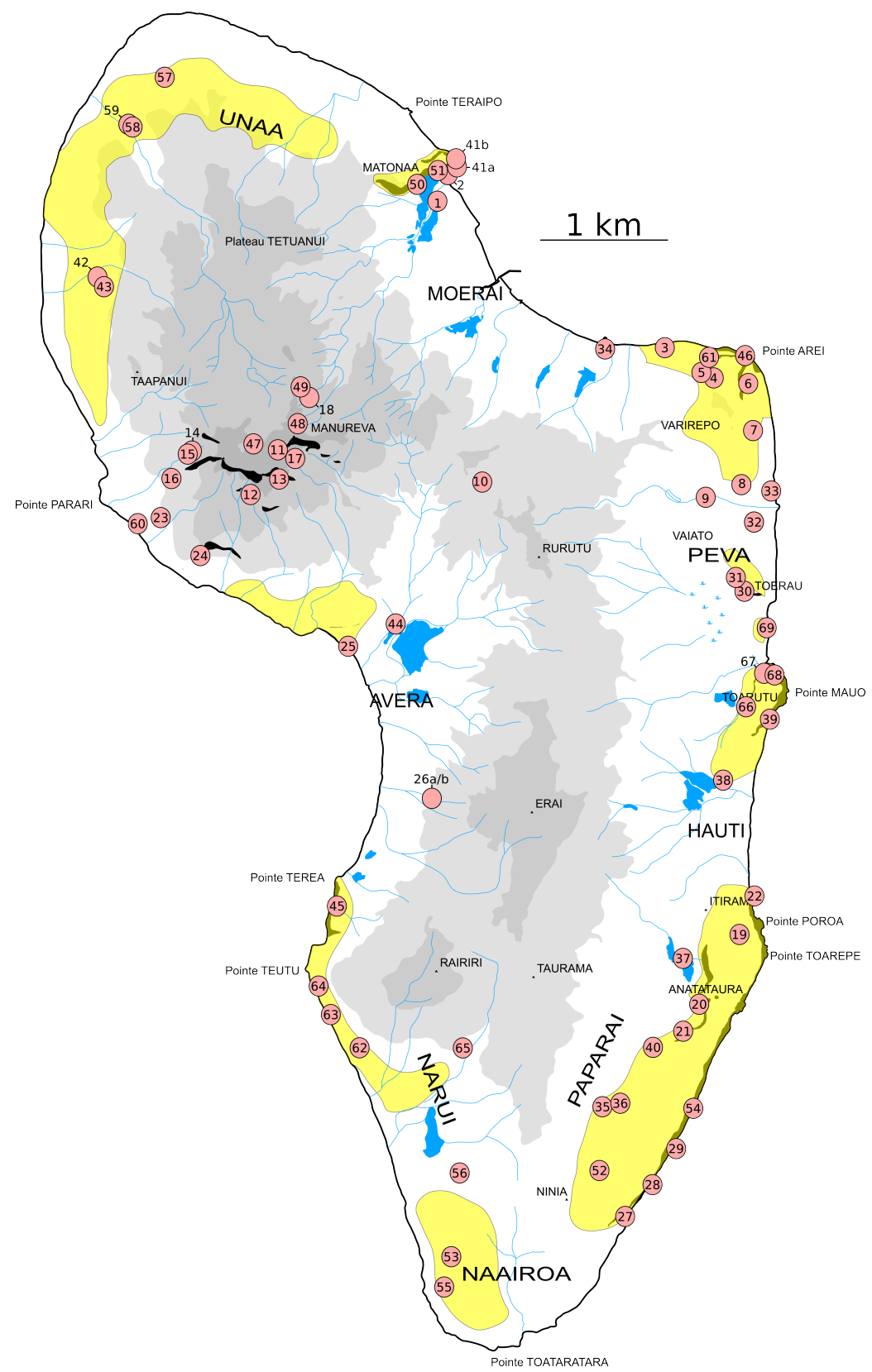

FIGURE 1. Physical map of Rurutu (French Polynesia), showing the sampled localities. Yellow represents areas of raised coral reef (matos). 


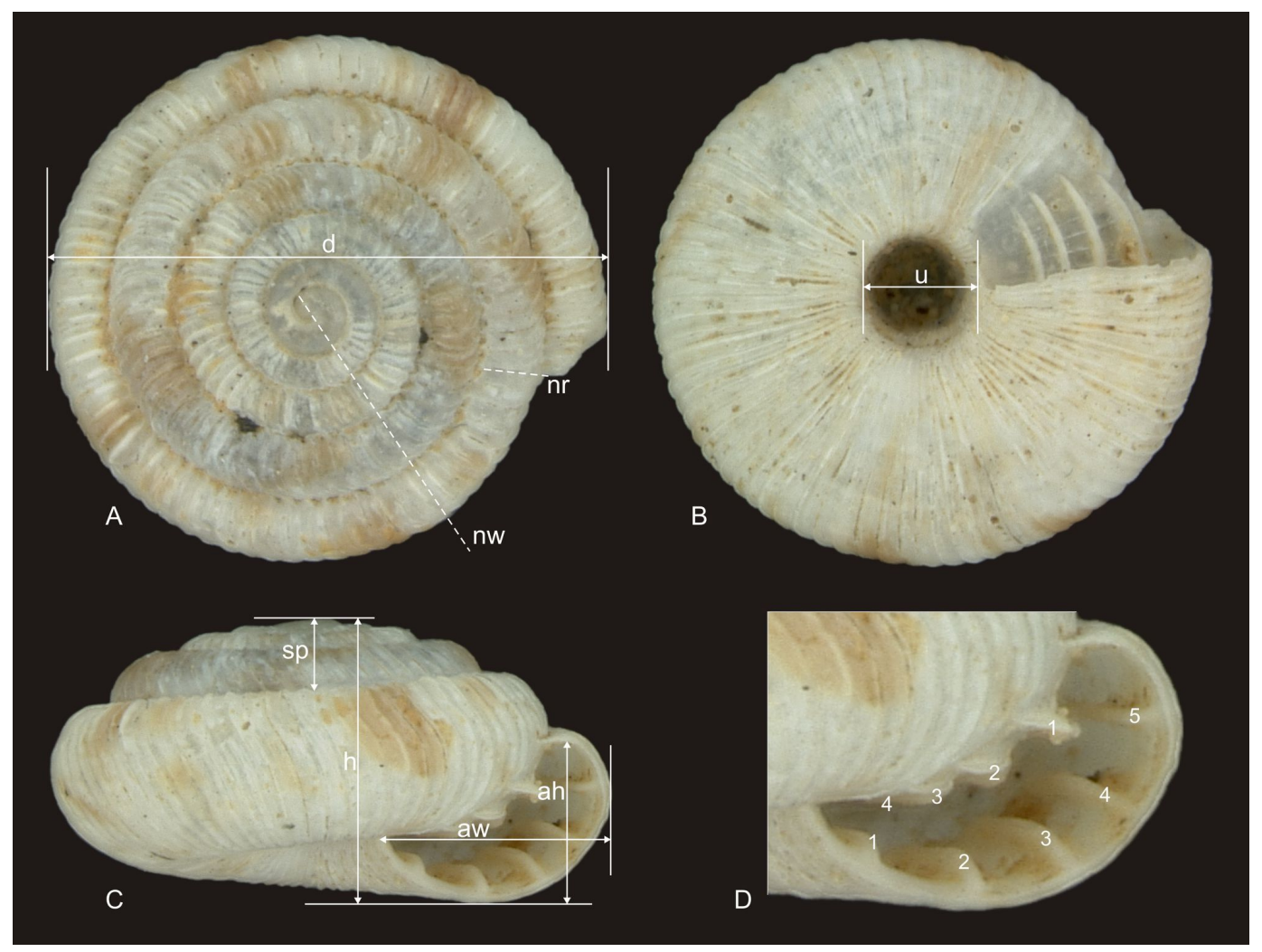

FIGURE 2. Photographs of Minidonta boucheti sp. nov. (station Rr30, d = $2.87 \mathrm{~mm}$ ) showing the placement of measurements $(\mathbf{A}-\mathbf{C})$ and numbering scheme for apertural barriers (D) used in this study. Abbreviations: ah, aperture height; aw, aperture width; d, shell diameter; h, shell height; nr, number of ribs on body whorl (counted from this line to the aperture); nw, number of whorls (line marks the boundary between whorls); sp, spire protrusion; $\mathrm{u}$, umbilicus diameter. 


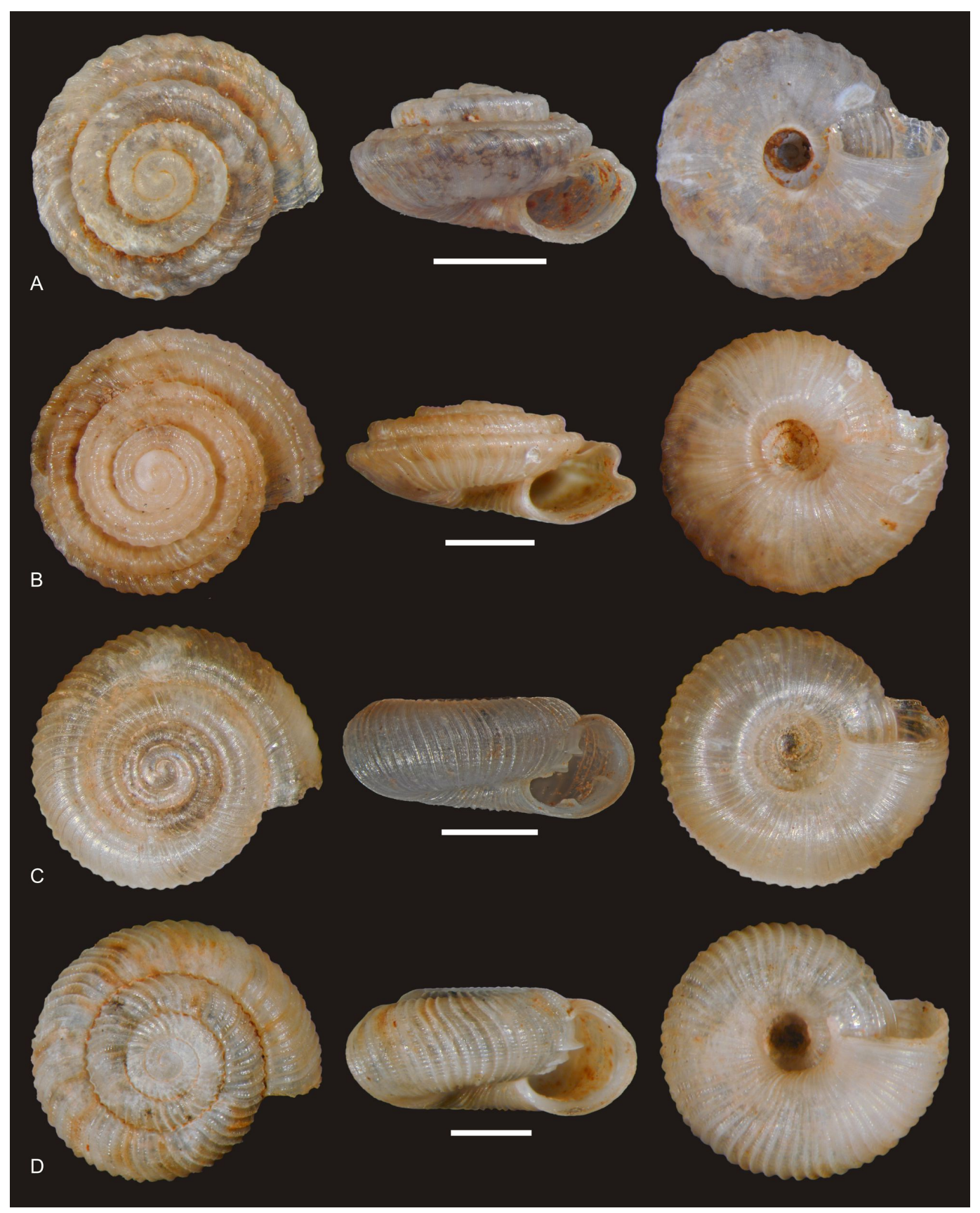

FIGURE 3. Holotypes of: A. Australdonta oheatora sp. nov.; B. A. anneae sp. nov.; C. A. sibleti sp. nov.; D. A. florencei sp. nov. Scale bars $=1 \mathrm{~mm}$. 


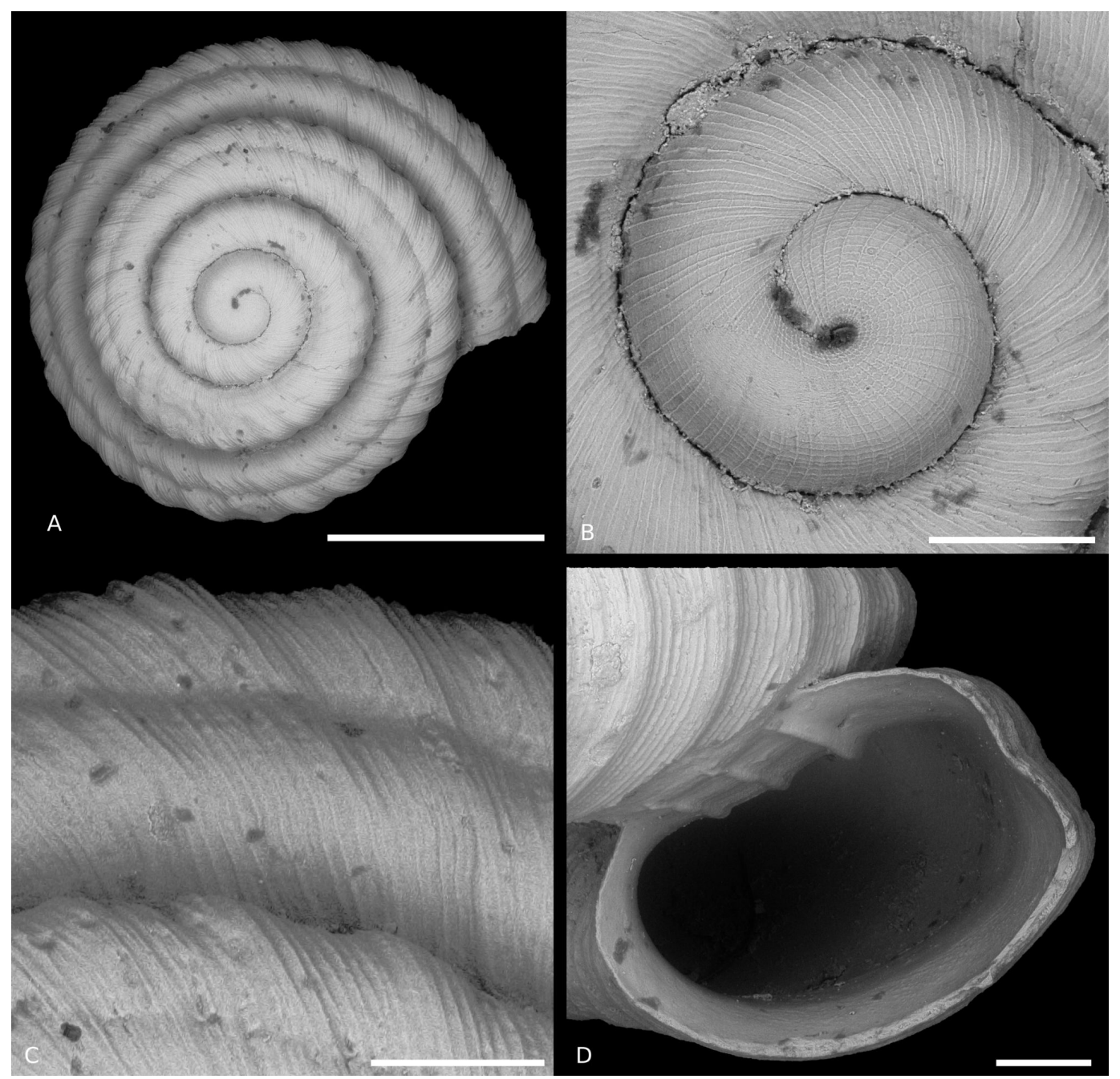

FIGURE 4. Australdonta oheatora sp. nov. A-C. Holotype (MNHN 25193), apical views; A. General view; B. Sculpture of the protoconch and early teleoconch; C. Sculpture of the late teleoconch; D. Paratype 3 (MNHN 25194), detail of the peristome. Scale bars: $\mathrm{A}=1 \mathrm{~mm}$; $\mathrm{B}-\mathrm{D}=200 \mu \mathrm{m}$. 


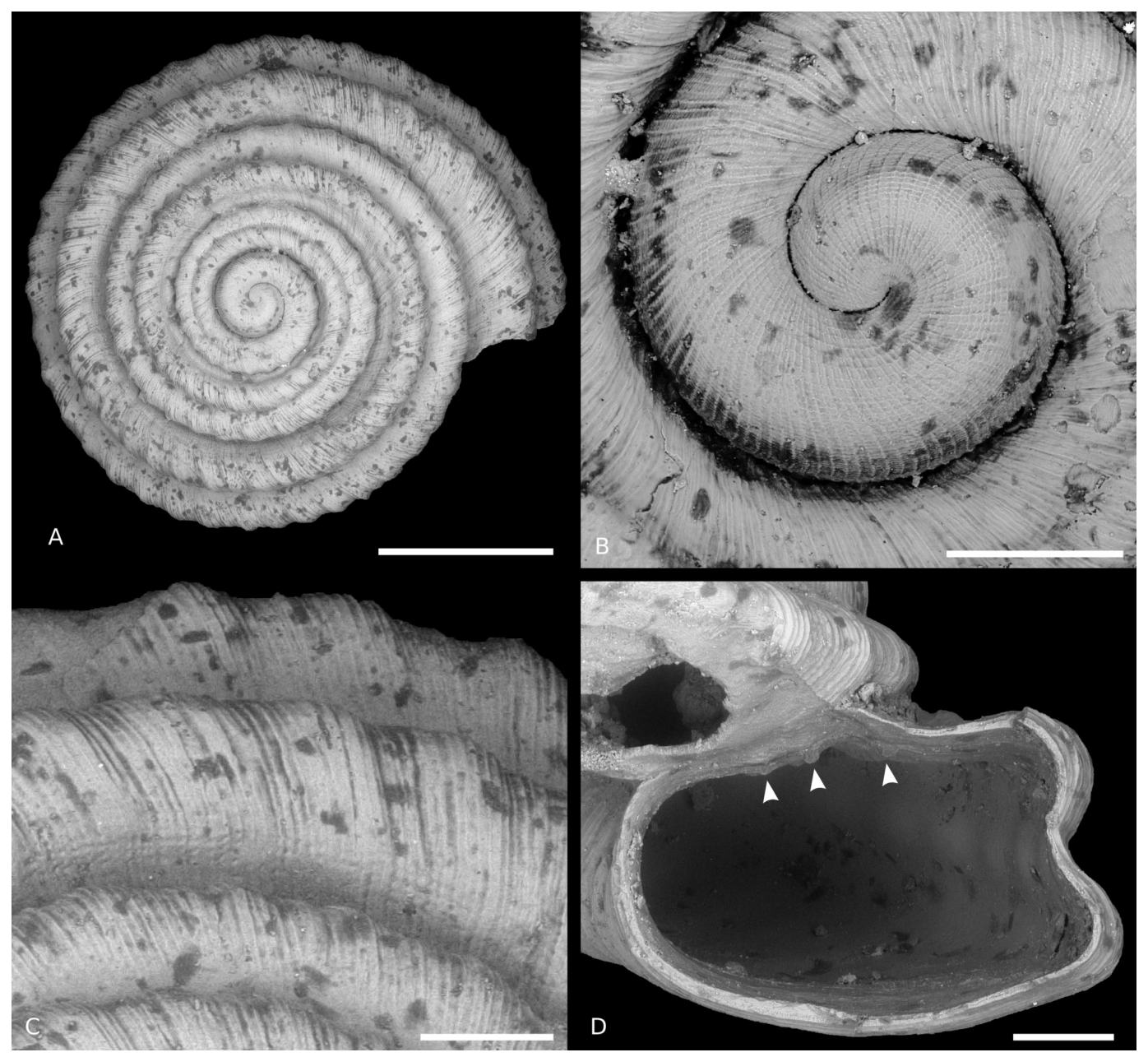

FIGURE 5. Australdonta anneae sp. nov. A-C. Holotype (MNHN 25197), apical views; A. General view; B. Sculpture of the protoconch and early teleoconch; C. Sculpture of the late teleoconch; D. Paratype 1 (MNHN 25198), detail of the peristome. Arrowheads indicate the traces of apertural barriers. Scale bars: $\mathrm{A}=1 \mathrm{~mm}$; $\mathrm{B}-\mathrm{D}=200 \mu \mathrm{m}$. 


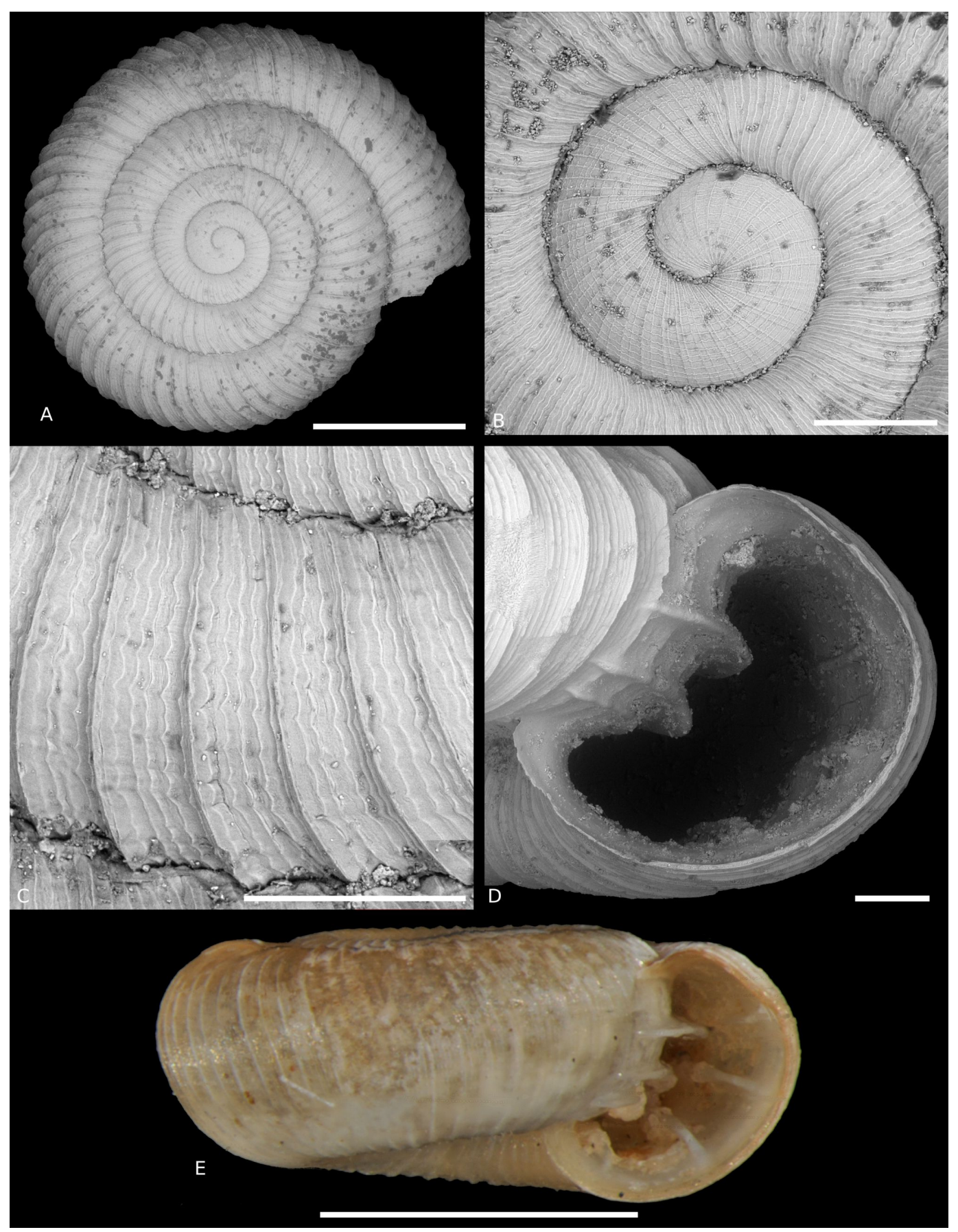

FIGURE 6. Australdonta sibleti sp. nov. A-C. Holotype (MNHN 25201), apical views; A. General view; B. Sculpture of the protoconch and early teleoconch; C. Sculpture of the late teleoconch; D. Paratype 6 (MNHN 25202), detail of the peristome; E. Specimen collected at station $\operatorname{Rr} 42$, showing prominent palatal barriers. Scale bars: A,E $=1 \mathrm{~mm}$; $-\mathrm{D}=200 \mu \mathrm{m}$. 


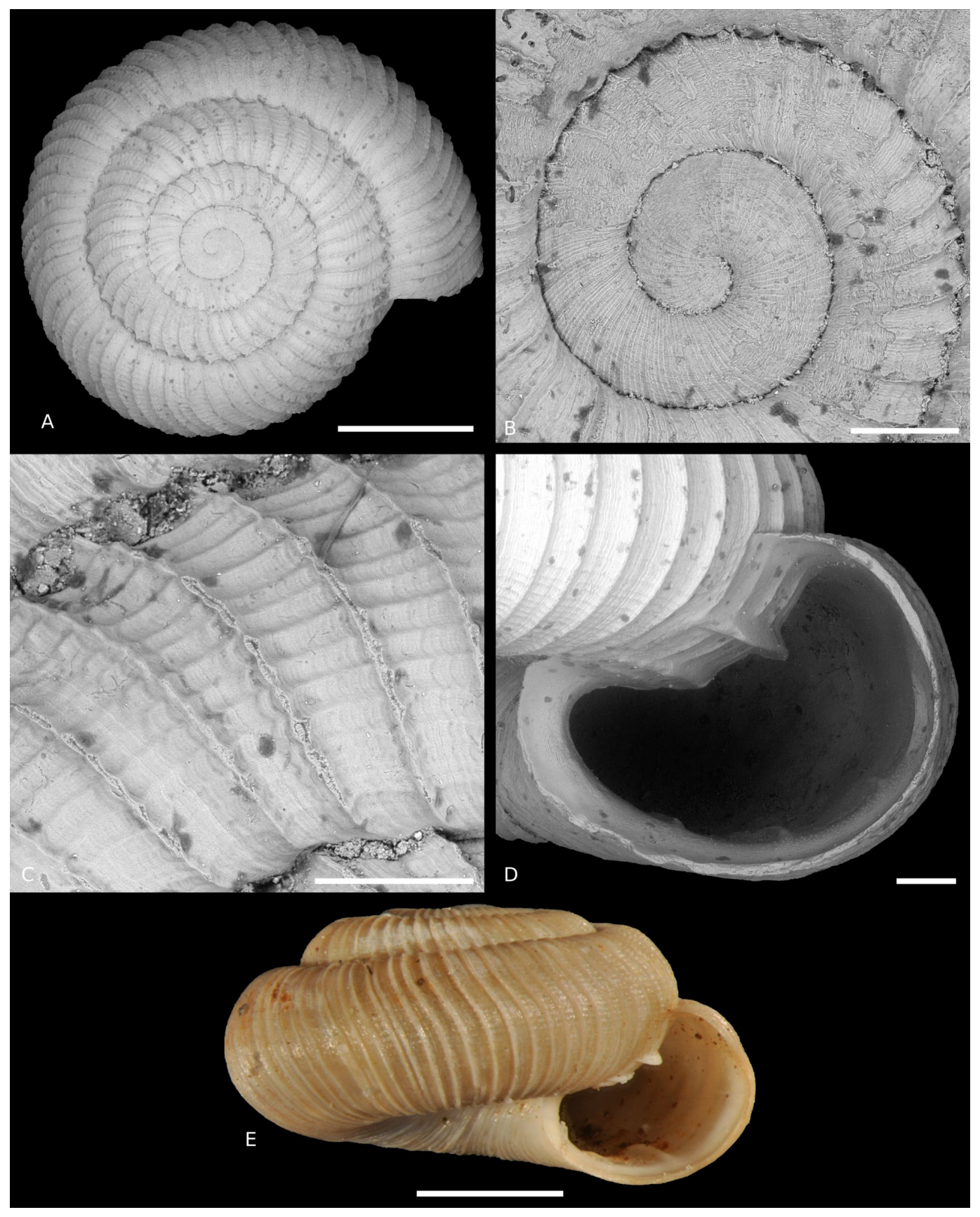

FIGURE 7. Australdonta florencei sp. nov. A-C. Holotype (MNHN 25203), apical views; A. General view; B. Sculpture of the protoconch and early teleoconch; C. Sculpture of the late teleoconch; D. Paratype 1 (MNHN 25204), detail of the peristome; E. Specimen from station Rr38, displaying an unusually high spire. Scale bars: A,E $=1 \mathrm{~mm} ; \mathrm{B}-\mathrm{D}=200 \mu \mathrm{m}$. 


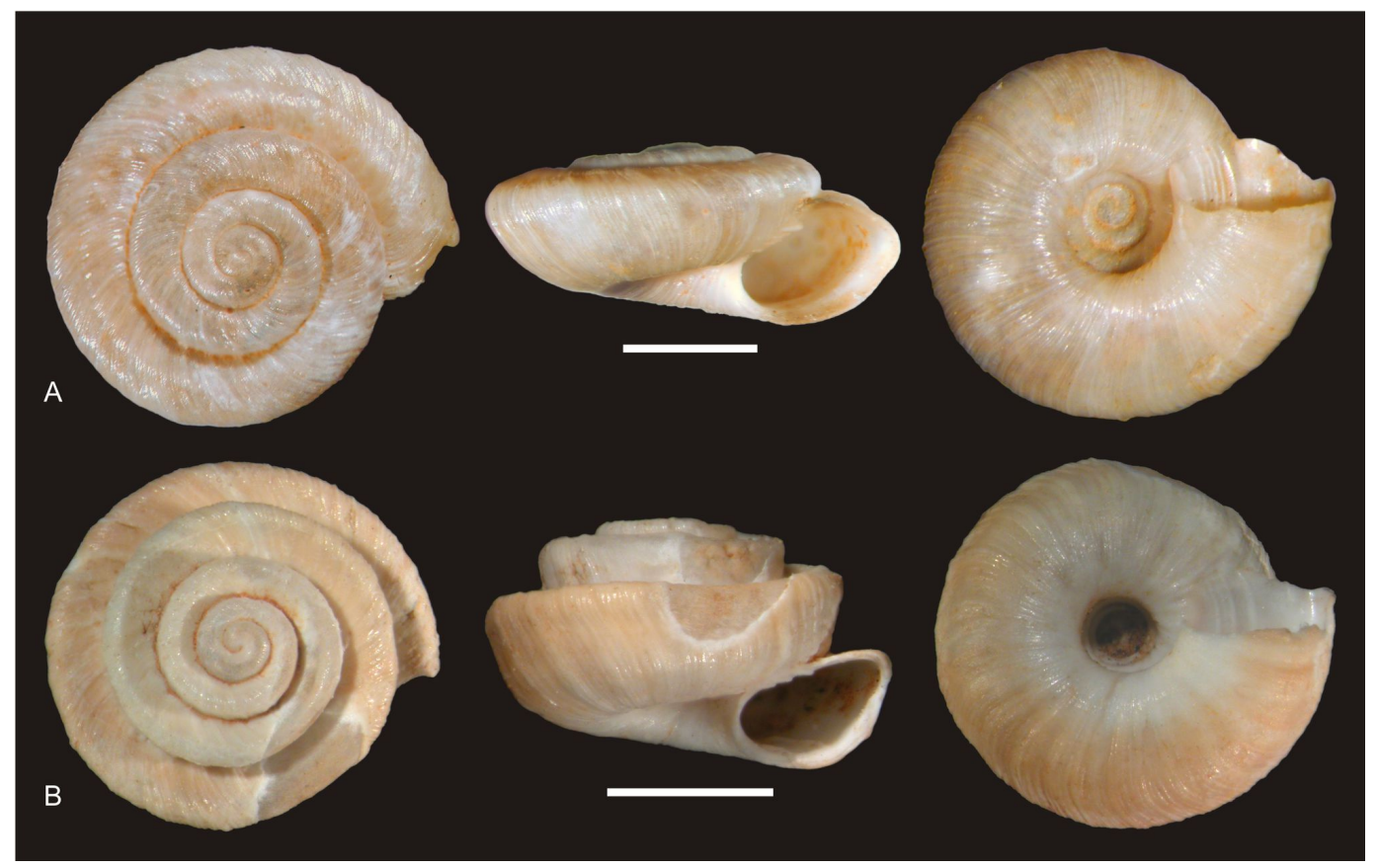

FIGURE 8. Australdonta pakalolo sp. nov. A. Holotype; B. Paratype. Scale bars $=1 \mathrm{~mm}$. 


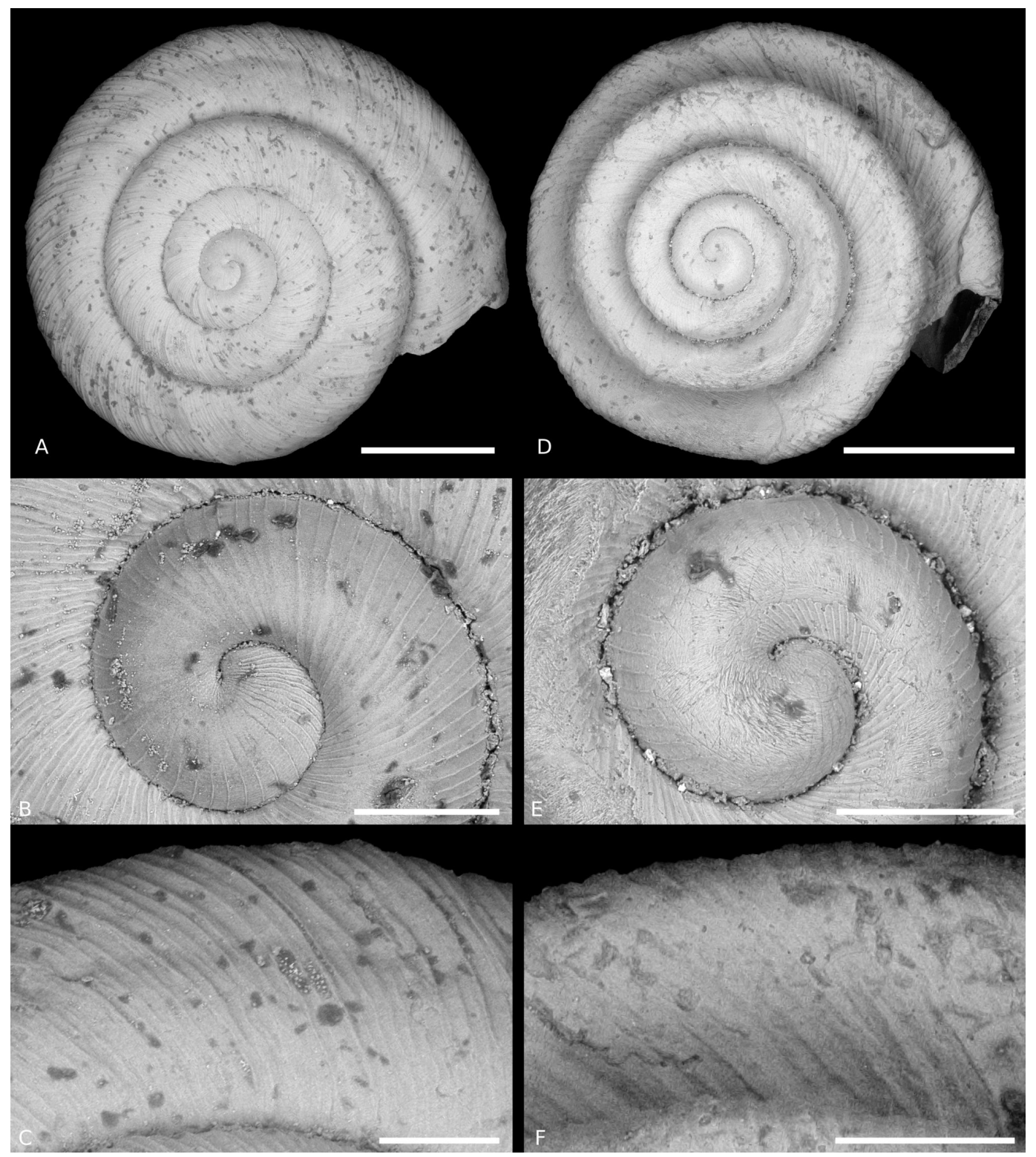

FIGURE 9. Australdonta pakalolo sp. nov. Apical views of the holotype (A$\mathbf{C}$ ) and paratype $(\mathbf{D}-\mathbf{F})$. A and D. General view; B and E. Sculpture of the protoconch and early teleoconch; $\mathbf{C}$ and $\mathbf{F}$. Sculpture of the late teleoconch. Scale bars: A,D $=800 \mu \mathrm{m} ; \mathrm{B}, \mathrm{C}, \mathrm{E}, \mathrm{F}=200 \mu \mathrm{m}$. 


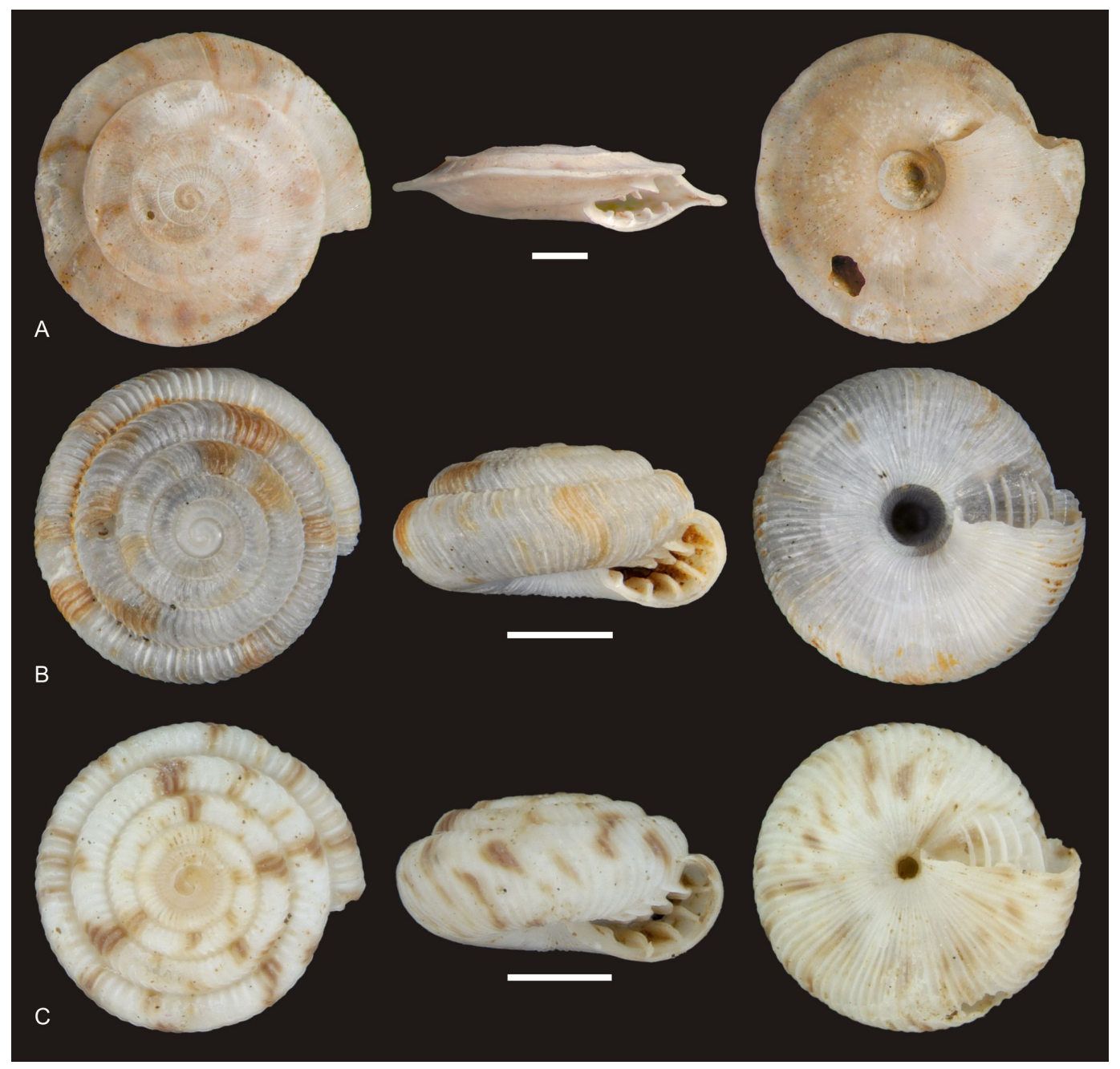

FIGURE 10. Holotypes of: A. Australdonta teaae sp. nov.; B. Minidonta boucheti sp. nov.; C. M. bieleri sp. nov. Scale bars $=1 \mathrm{~mm}$. 


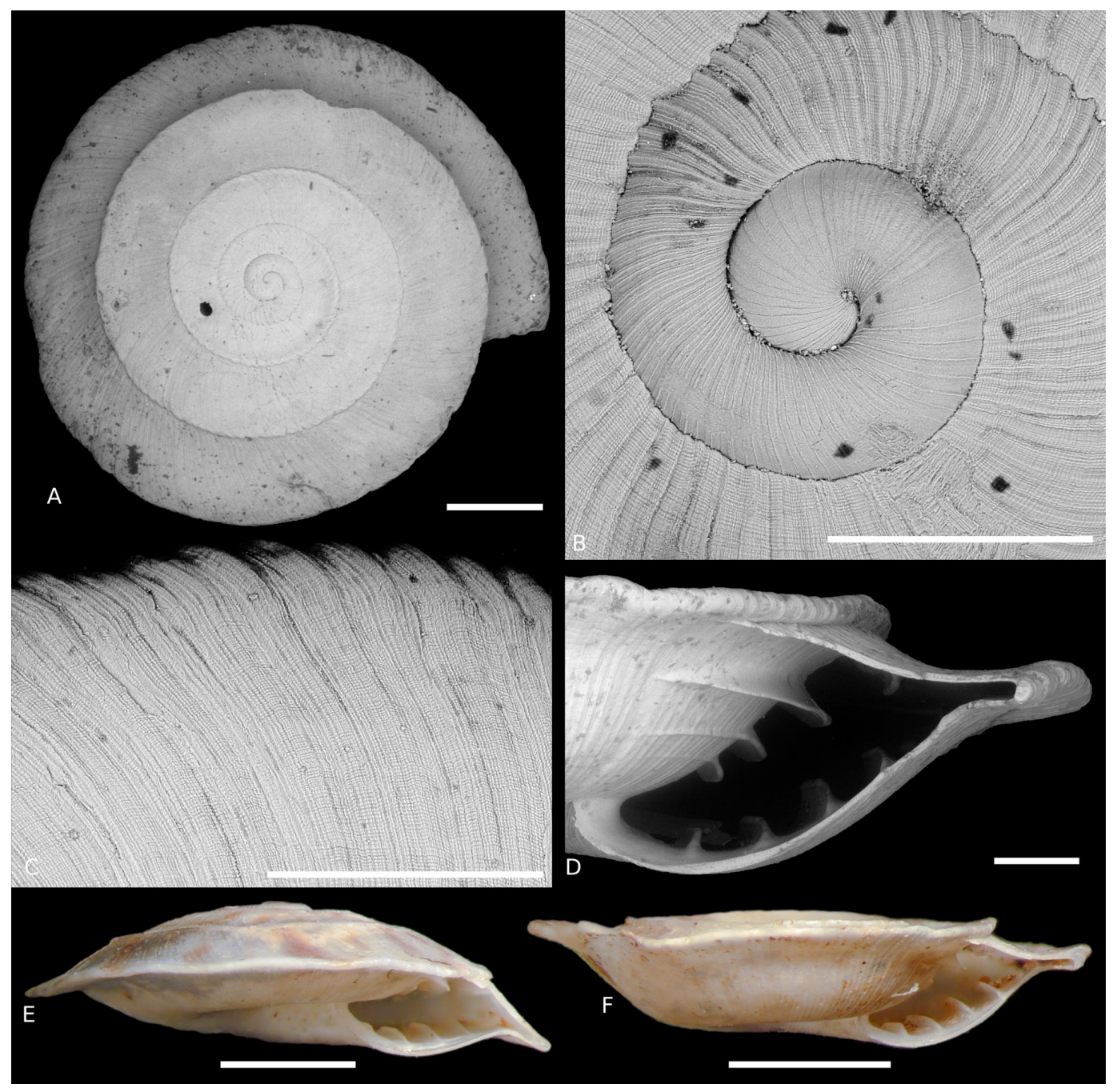

FIGURE 11. Australdonta teaae sp. nov. A. Holotype (MNHN 25205), apical view; B and C. Paratype 6 (MNHN 25206); B. Sculpture of the protoconch and early teleoconch; C. Sculpture of the late teleoconch; D. Paratype 2 (MNHN 25206), detail of the peristome; E. Paratype 1 (MNHN 25206), displaying a moderately raised spire; F. Paratype 2, displaying a flat spire. Scale bars: $\mathrm{A}=1 \mathrm{~mm} ; \mathrm{B}-\mathrm{D}=400 \mu \mathrm{m} ; \mathrm{E}-\mathrm{F}=2 \mathrm{~mm}$. 


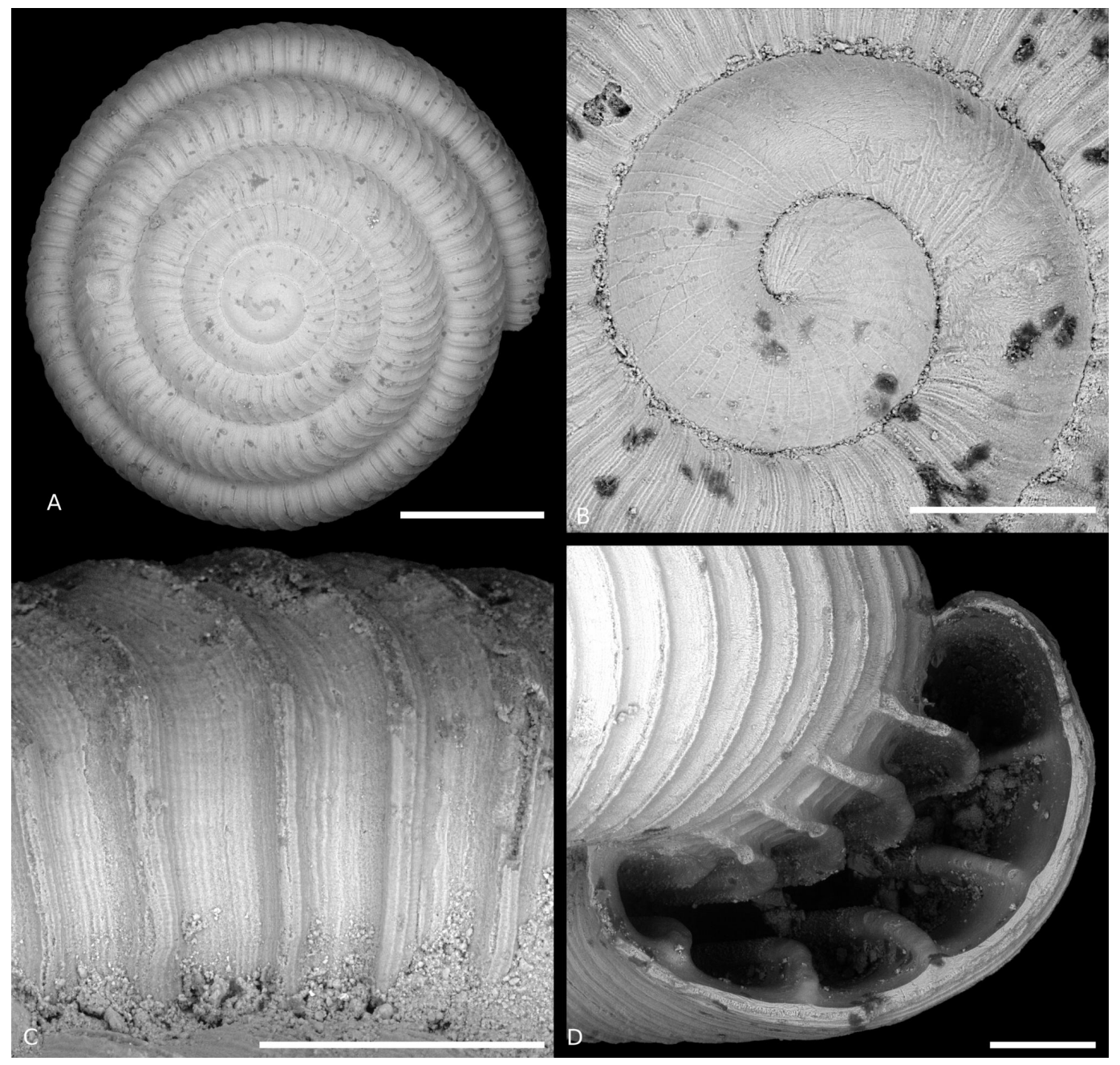

FIGURE 12. Minidonta boucheti sp. nov. A and C. Holotype (MNHN 25207), apical views; A. General view; B. Sculpture of the protoconch and early teleoconch (specimen from Rr42); C. Sculpture of the late teleoconch; D. Paratype 8 (MNHN 25208), detail of the peristome. Scale bars: $A=800$ $\mu \mathrm{m} ; \mathrm{B}-\mathrm{D}=200 \mu \mathrm{m}$. 


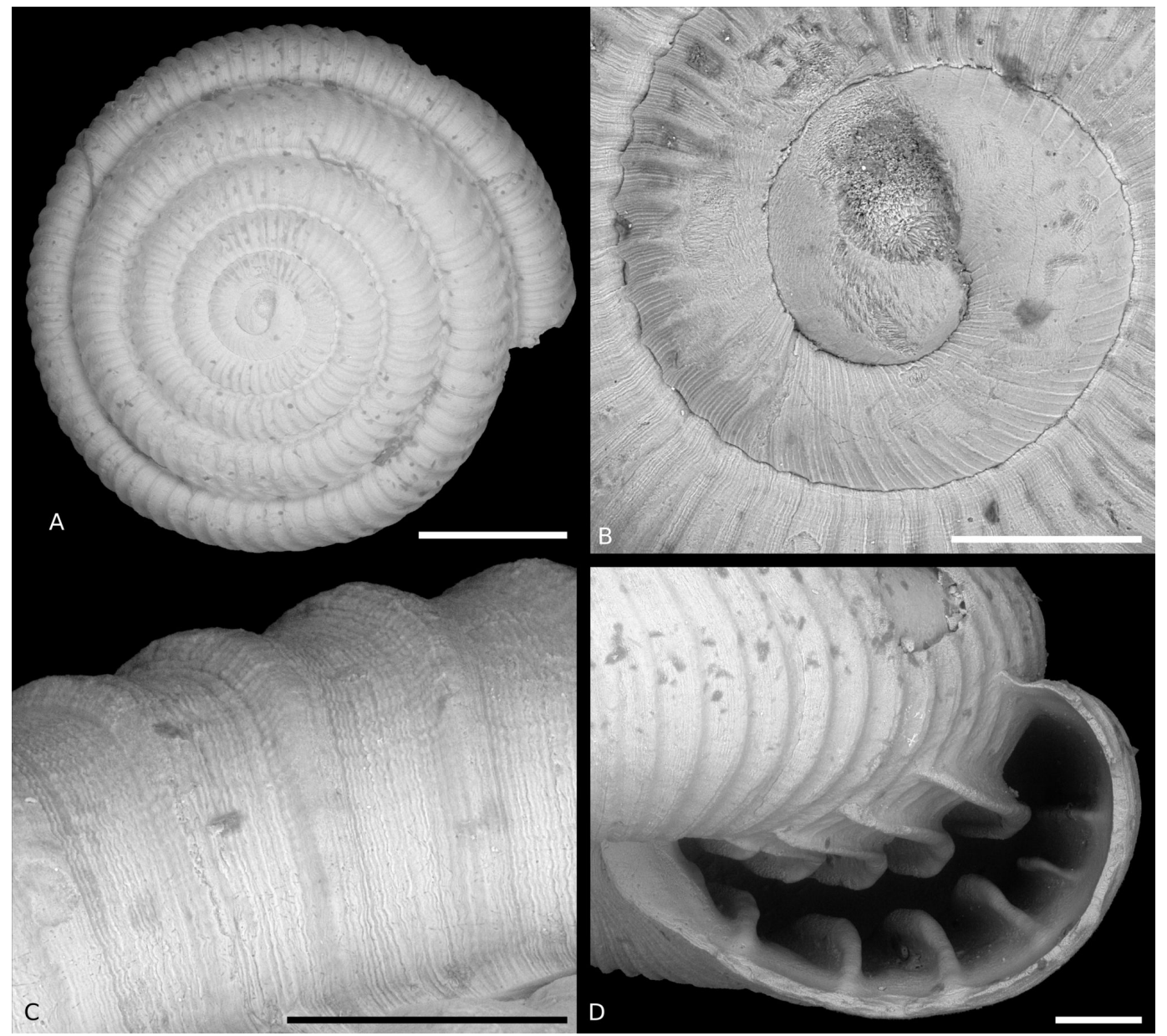

FIGURE 13. Minidonta bieleri sp. nov. A-C. Holotype (MNHN 25209), apical views; A. General view; B. Sculpture of the protoconch and early teleoconch; C. Sculpture of the late teleoconch; D. Paratype 1 (MNHN 25211), detail of the peristome. Scale bars: $A=800 \mu \mathrm{m} ; \mathrm{B}-\mathrm{D}=200 \mu \mathrm{m}$. 


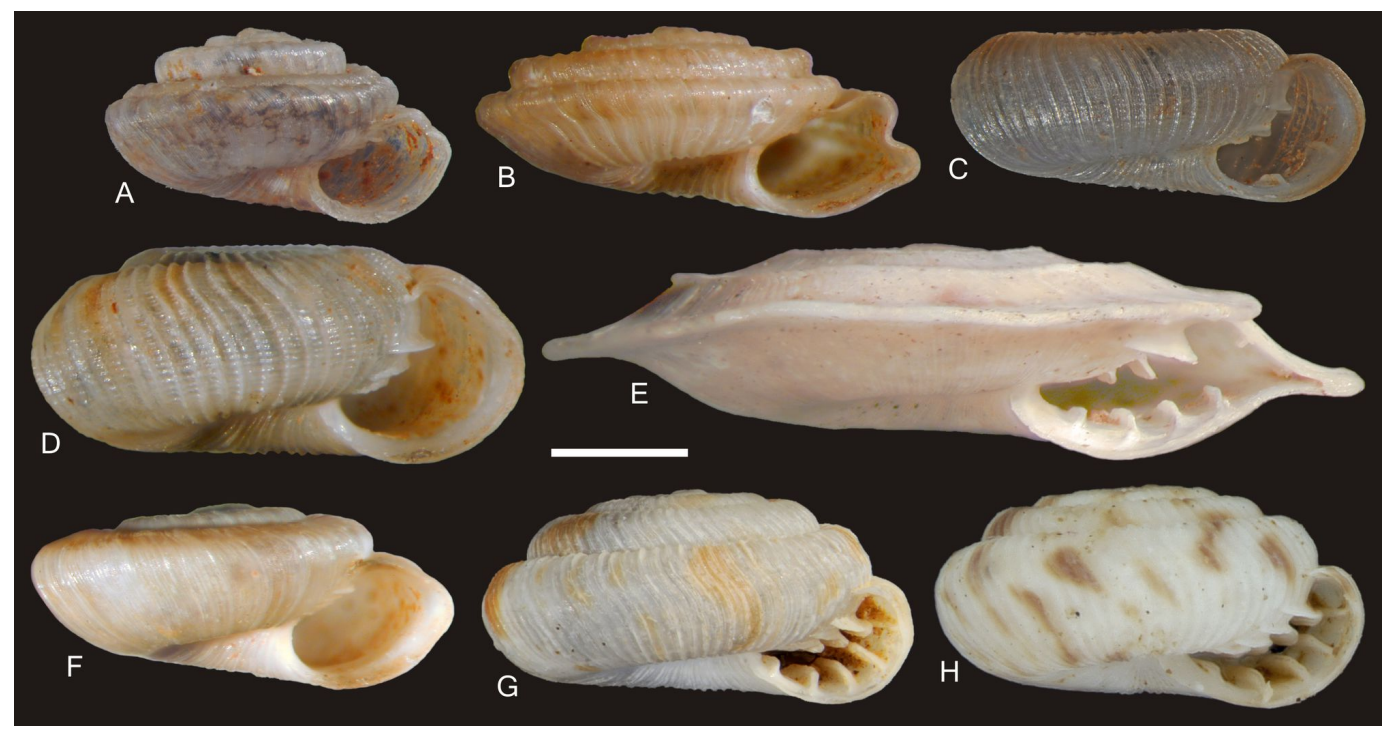

FIGURE 14. Apertural view of the holotypes of the new species described herein, illustrated at the same scale: A. Australdonta oheatora sp. nov.; B. A. anneae sp. nov.; C. A. sibleti sp. nov.; D. A. florencei sp. nov.; E. A. teaae sp. nov.; F. A. pakalolo sp. nov.; G. Minidonta boucheti sp. nov.; H. M. bieleri sp. nov. Scale bar $=1 \mathrm{~mm}$. 


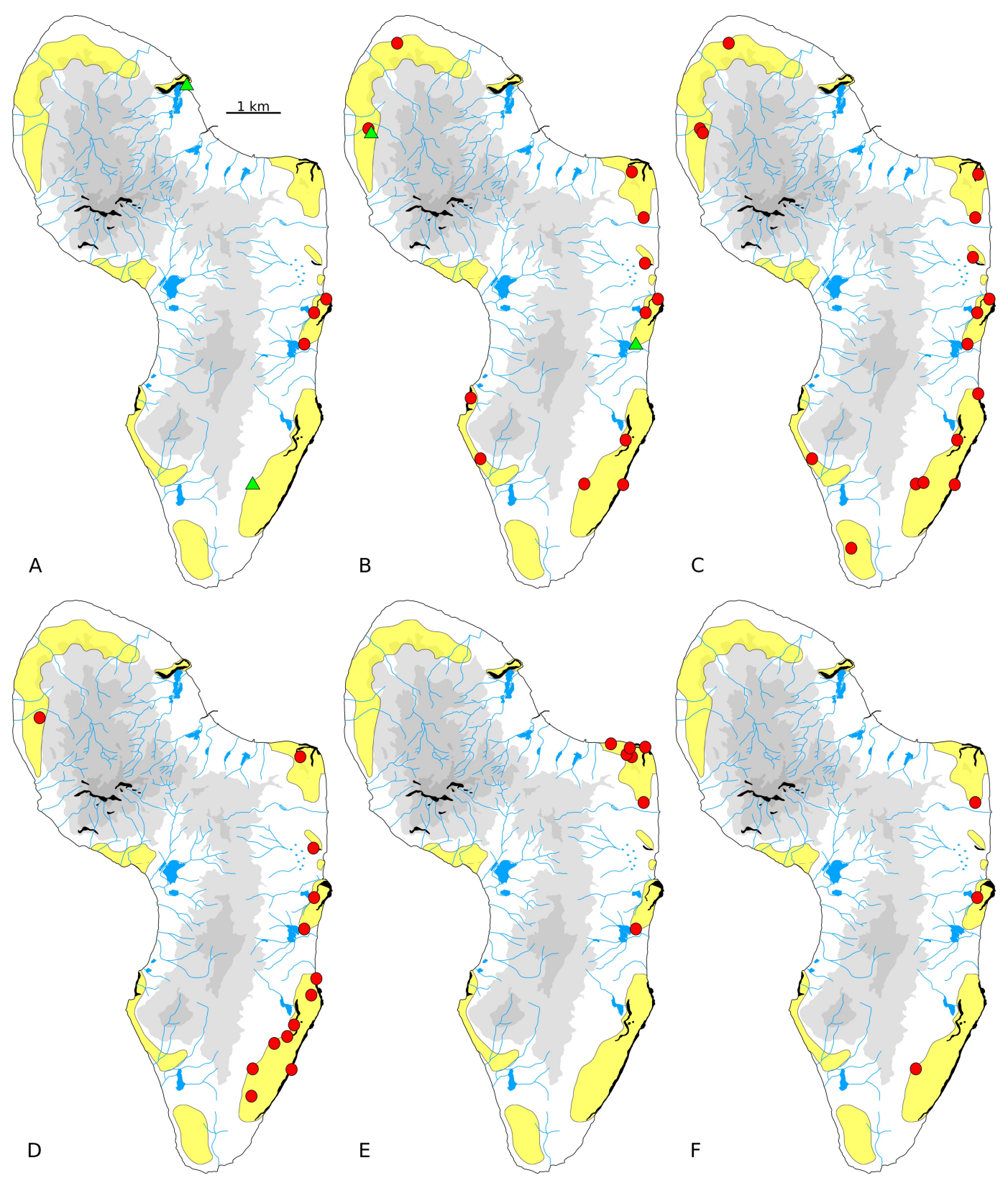

FIGURE 15. Physical map of Rurutu (French Polynesia), showing the distribution of the new species of Endodontidae described herein; yellow represents areas of raised coral reef (matos). A. circles, Australdonta oheatora; triangle, A. pakalolo. B. circles, Minidonta boucheti; triangles, A. anneae. C. A. sibleti. D. A. florencei. E. A. teaae. F. M. bieleri. 


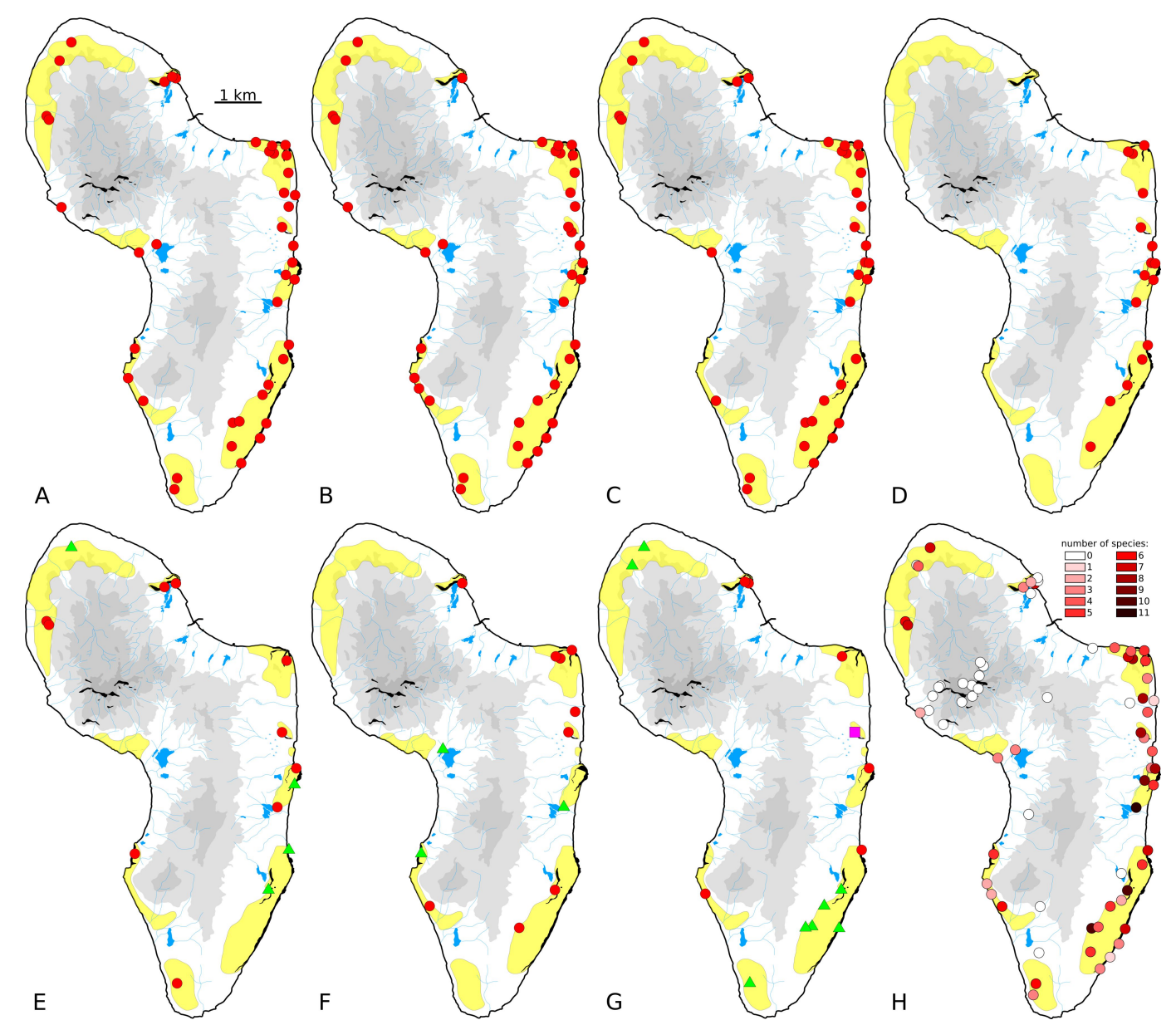

FIGURE 16. Physical map of Rurutu (French Polynesia), showing the distribution of previously known species of Endodontidae $(\mathbf{A}-\mathbf{G})$, and a summary of species richness per station $(\mathbf{H})$; yellow represents areas of raised coral reef (matos). A. Australdonta degagei. B. A. tapina. C. A. pseudplanulata. D. A. collicella. E. circles, A. yoshii; triangles, A. sulcata. F. circles, A. magnasulcata; triangles, A. radiella rurutuensis. G. circles, Minidonta haplaenopla; triangles, A. microspiralis; square, A. magnasulcatissima. H. species richness indicated by gradient of color from white (zero endodontid species) to very dark red (eleven endodontid species). 